\title{
The KH domain protein encoded by quaking functions as a dimer and is essential for notochord development in Xenopus embryos
}

\author{
Aaron M. Zom ${ }^{1-3}$ and Paul A. Krieg \\ ${ }^{1}$ Center for Developmental Biology, Department of Zoology, University of Texas at Austin, Austin, Texas 78712 USA; \\ ${ }^{2}$ Well Icome/Cancer Research Campaign (CRC) Institute of Cancer and Developmental Biology, Cambridge CB2 1QR, UK
}

\begin{abstract}
Mutations in the mouse indicate that quaking gene function is essential for both embryogenesis and for development of the nervous system. Recent isolation of the mouse quaking gene identified a putative RNA-binding protein containing a single KH domain. We have previously isolated the Xenopus homolog of quaking, Xqua, and shown that the sequence is highly conserved through evolution. Here, we report experimental data on the biochemical function of the quaking protein and its role during development. We demonstrate that the quaking protein expressed during early embryogenesis, pXqua ${ }^{357}$, can bind RNA in vitro, and we have mapped the regions of the protein that are essential for RNA binding. We present evidence that pXqua can form homodimers and that dimerization may be required for RNA binding Oocyte injection

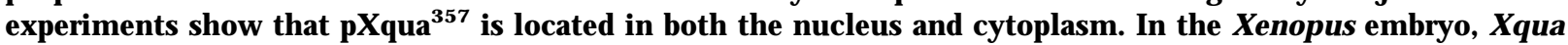
is first expressed during gastrulation in the organizer region and its derivative, the notochord. In later stage embryos, Xqua is expressed in a number of mesodermal and neural tissues. We demonstrate that disruption of normal Xqua function, by overexpression of a dominant inhibitory form of the protein, blocks notochord differentiation. Xqua function appears to be required for the accumulation of important mRNAs such as Xnot, $\mathrm{Xbra}$, and gsc. These results indicate an essential role for the quaking RNA-binding protein during early vertebrate embryogenesis.
\end{abstract}

[Key Words: quaking; Xqua; KH domain; RNA binding; notochord; Xenopus]

Received February 17, 1997; revised version accepted July 11, 1997.

The function of the murine quaking gene product is required both during embryogenesis and during later development of the nervous system as indicated by two classes of mutant recessive quaking alleles. Mice that are homozygous for the quaking viable allele $\left(\mathrm{qk}^{\mathrm{v}} / \mathrm{qk}^{\mathrm{v}}\right)$ have a deficiency of myelin in their nervous system and exhibit a characteristic tremor or "quaking" of the hind quarters (Sidman etal. 1964; Samorajski et al. 1970). The second class of quaking alleles, $\mathrm{qk}^{\mathrm{el}-4} / \mathrm{qk}^{\mathrm{el}-4}$, are embryonic lethal around day 9-10 of gestation (Bode 1984; Justice and Bode 1988; Shedlovsky et al. 1988). The mutant embryos are disorganized and exhibit generalized atrophy, but the precise cause of lethality has not been characterized (Justice and Bode 1988).

The sequence of the recently cloned mouse quaking gene (qkl) (Ebersole et al. 1996) and its human (H qk) and Xenopus (Xqua) homologs (Zorn et al . 1997) indicate that quaking encodes a $\mathrm{KH}$ domain RNA-binding protein. $\mathrm{The} \mathrm{KH}$ domain is an evolutionarily conserved sequence

${ }^{3}$ Corresponding author.

E-MAIL amz@molebio.cam.ac.uk; FAX 01223-334089. found in a diversity of proteins, most of which are implicated in some aspect of RNA metabolism (Gibson et al. 1993; Siomi et al. 1993a). N otable examples include the heterogeneous nuclear ribonucleoprotein K (hnRN P K) (Siomi et al. 1993a) and the human Fragile X Syndrome gene, FMR1 (Siomi et al. 1993b). Experimental evidence indicates that the $\mathrm{KH}$ domain is directly involved in RNA binding. For example, a particularly severe allele of the Fragile $X$ Syndrome (De Boulle et al. 1993) is caused by a single point mutation in a conserved residue in the second $\mathrm{KH}$ domain, resulting in a mutant protein that shows dramatically reduced RNA-binding activity (Siomi et al. 1994). quaking belongs to a new subclass of $\mathrm{KH}$ proteins, called GSG domain proteins (Jones and Schedl 1995; Ebersole et al. 1996), based on sequence similarity with GLD-1, a tumor suppressor gene required for germ line development in Caenorhabditis elegans (Jones and Schedl 1995); SAM 68, a mammalian phosphoprotein involved in the Src signaling pathways during mitosis (Won et al. 1992; Fumagalli et al. 1994; Taylor and Shalloway 1994; Lock et al. 1996); and GRP33, an hnRNP isol ated from brineshrimp (C ruz- 
Alvarez and Pellicer 1987). GSG proteins are characterized by an 200 -amino-acid regi on of sequence similarity centered on a single $\mathrm{KH}$ motif. Although the $\mathrm{KH}$ domain is highly conserved between GSG family members, it is rather divergent from the $\mathrm{KH}$ motifs found in other proteins.

The $\mathrm{qk}^{\vee}$ defect is a classic model for the study of dismyel ination, and a wealth of literature describes various aspects of the defective nervous system (Hogan and Greenfield 1984). Despite this intense investigation, the precise role of quaking in neural development remains obscure, and even less is understood about its function during early embryogenesis. The mouse qkl gene produces three transcripts $5 \mathrm{~kb}, 6 \mathrm{~kb}$, and $7 \mathrm{~kb}$ in length, generated by alternative mRN A splicing. The sequences of the proteins resulting from these transcripts are identical except for the extreme carboxy-terminal region (Ebersole et al. 1996). In Xenopus, 5-kb and 5.5-kb mRN As (analogous to the mouse $5-\mathrm{kb}$ and $6-\mathrm{kb}$ mRNAs) have been observed (Zorn et al . 1997). In both frog and mouse only the 5-kb mRNA is expressed in the early embryo, with the 6-kb form arising later in development. Expression of the $5-\mathrm{kb}$ and $6-\mathrm{kb}$ sequences continues throughout development, and in the adult mouse, the transcripts are abundant in the brain, lung, heart, and testis (Ebersole et al. 1996). Expression of the 7-kb mRN A is apparently restricted to the adult brain. The fact that $\mathrm{qkl}$ is expressed in a variety of tissues and that quaking mutati ons have pleiotropic effects suggests that quaking function is important for the development or maintenance of a number of cell types. Furthermore, the remarkable $94 \%$ conservation of the mouse, human, and Xenopus protein sequences (Zorn et al. 1997) suggests that the quaking biochemical pathway is highly conserved through evolution.

A number of $\mathrm{KH}$ domain RNA-binding proteins are known to be required during development of invertebrates. These include Bicaudal-C in Drosophila, which is essential for anterior-posterior specification (M ahone et al. 1995); gld-1, which encodes a GSG protein that is essential for germ line development in C. elegans (Jones and Schedl 1995); and mex-3, which regulates early blastomere identity in the $\mathrm{C}$. el egans embryo (Draper et al. 1996). quaking is one of the first examples of a $\mathrm{KH}$ domain protein essential for early vertebrate embryogenesis. In an effort to understand the developmental function of the quaking protein, we have characterized the biochemical properties of pXqua ${ }^{357}$, the Xenopus quaking protein that is expressed during early embryonic development. We have mapped the regions of pXqua ${ }^{357}$ that are essential for RN A binding and present evidence that pXqua proteins can form homodi mers. These results have implications not only for quaking but al so for understanding the general biochemical properties of the GSG subfamily of KH domain proteins. Finally, we demonstrate that embryonic overexpression of pXqua ${ }^{357}$ enhances notochord devel opment, whereas overexpression of a dominant inhibitory pXqua mutant disrupts the endogenous Xqua pathway and blocks notochord development. The normal function of Xqua appears to be essen- tial for the accumulation of important mRN As such as Xnot, Xbra, and goosecoid (gsc). Our findings provide a possible explanation for the early embryonic lethal ity of quaking mutant embryos.

\section{Results}

pXqua binds RNA in vitro

The presence of a $\mathrm{KH}$ motif in the quaking protein (Ebersole et al. 1996; Zorn et al. 1997) suggests that it is an RNA-binding protein. To directly test this possibility, we have examined the in vitro RN A-binding properties of Xenopus quaking proteins pXqua ${ }^{357}$ and pXqua ${ }^{365}$, which are identical except for an 8-amino-acid insertion just carboxy-terminal to the GSG domain, generated by alternative splicing (Zorn et al. 1997) (Fig. 1A). In vitro ${ }^{35}$ S-labeled Xqua proteins were assayed for the ability to bind RNA immobilized on agarose beads (Swanson and Dreyfuss 1988). As shown in Figure 1B, both pXqua ${ }^{357}$ and $\mathrm{pXqua} \mathrm{a}^{365}$ bind total Xenopus embryonic RN A but do not bind significantly to agarose alone. We examined whether pXqua had a preference for the type of RNA it would bind by using different RNA homopolymers coupled to agarose. Both pXqua ${ }^{357}$ and $\mathrm{pXqua}^{365}$ bind preferentially to poly(rG) and poly(rU) RNA, whereas neither binds significantly to poly(rA) or poly(rC) RN A (Fig. 1B), indicating that pXqua has some specificity in its interaction with RNA. Because pXqua ${ }^{357}$ and $p X$ qua $^{365}$ exhibit indistingui shable RN A-binding properties in this assay, only pXqua ${ }^{357}$ was used in subsequent experiments. The strength of the RNA-protein interactions was examined by increasing the salt concentration of the binding assay. As shown in Figure $1 C$, recombinant $\mathrm{pXqua}{ }^{357}$ binds weakly to total embryonic RNA and poly(rU), neither interaction being stable in $250 \mathrm{~mm}$ $\mathrm{NaCl}$. However, pXqua ${ }^{357}$ shows a much stronger interaction with poly(rG) RNA, retaining some binding up to $500 \mathrm{~mm}$. In additional experiments, pXqua ${ }^{357}$ exhibited weak binding to single-stranded DNA-agarose, but no detectable binding to double-stranded DNA-agarose (data not shown). The nucleic acid binding properties of pXqua are comparable with those of RNA-binding proteins reported previously (Piñol-Roma et al . 1987; Swanson and Dreyfuss 1988; Siomi et al. 1993b).

The $\mathrm{KH}$ domain and the carboxy-terminal region are required for RNA binding in vitro

quaking and the other members of the GSG subfamily are characterized by a single $\mathrm{KH}$ motif. They are therefore distinct from most previously studied $\mathrm{KH}$ proteins that contain multiple KH motifs (Gibson et al. 1993; Si omi et al. 1993a,b). Detailed RN A-binding studies of hnRNP K and FMR1, for example, have shown that cooperativity between the multiple $\mathrm{KH}$ domains is required for full RNA binding and that deletion of any one $\mathrm{KH}$ motif practically abolishes RNA-binding activity (Siomi et al. 1994). In light of this, it is important to determine which regions of $\mathrm{pXqua}$ are required for its 
A

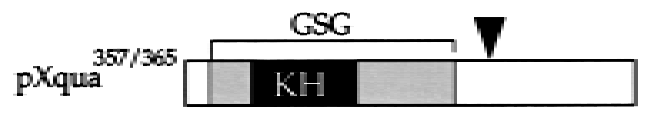

B
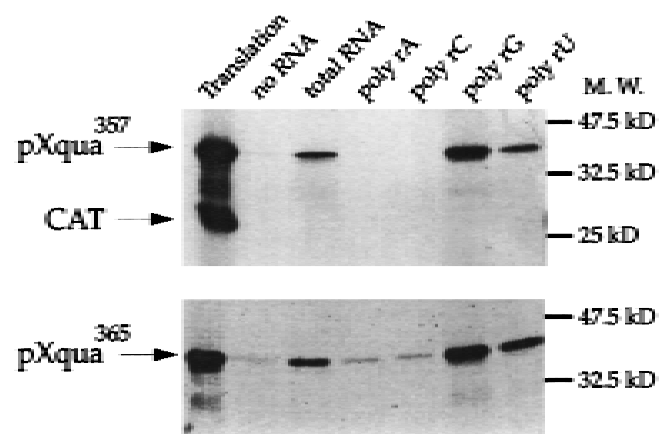

C

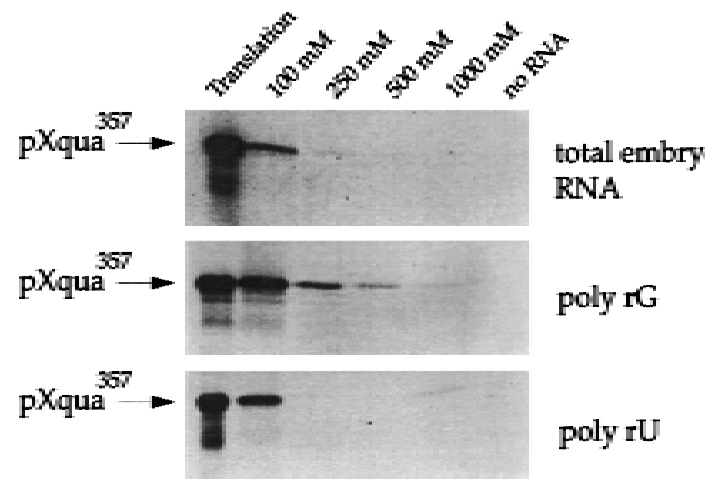

Figure 1. pXqua is an RNA-binding protein. (A) Two alternatively spliced forms of the $5-\mathrm{kb}$ Xqua mRN A are predicted to encode proteins of 357 ( $p X q u a^{357}$ ) and 365 ( $p X_{\text {qua }}{ }^{365}$ ) amino acids, respectively. The position of the al ternative exon is indicated by the arrowhead. pXqua bel ongs to the GSG subfamily of $\mathrm{KH}$ domain proteins, characterized by a single $\mathrm{KH}$ motif (in black) found in a larger 200 -amino-acid region of conserved sequence (in grey). To test for RN A-binding activity, ${ }^{35} \mathrm{~S}$-label ed pXqua $^{365}$, pXqua ${ }^{357}$, or an irrel evant control protein, CAT, were incubated with total embryonic RNA-agarose, homopolymer RN A-agarose, or agarose with no RNA. Proteins bound to the RNA-agarose were resolved by SDS-PAGE and visualized by fluorography. (B) The RN A-binding properties of pXqua ${ }^{357}$ and pXqua ${ }^{365}$ are indistinguishable, binding to total Xenopus embryonic RN A, poly $(r G)$, and poly $(r U) R N A$ but not to poly $(r A)$ or poly $(r C)$. The control CAT protein did not bind to the RNAagarose. An amount equal to $20 \%$ of the protein used in each binding reaction is shown in the track marked translation. (C) The relative RN A-binding strength of $p \mathrm{Xqua}^{357}$ to total embryonic RNA, poly(rU) RNA, and poly(rG) RNA was tested by increasing the salt concentrations of the binding reactions from $100 \mathrm{~mm}$ to $250 \mathrm{~mm}, 500 \mathrm{~mm}$, and $1 \mathrm{~m} \mathrm{NaCl}$. pXqua ${ }^{357}$ binds total Xenopus embryonic RN A and poly(rU) at moderate strength but binds most strongly to poly(rG).

RN A-binding activity. We therefore generated a series of truncated pXqua proteins (Fig. 2A) and assayed for in vitro RNA-binding activity (Fig. 2B). Truncation of the amino-terminal region up to the $\mathrm{KH}$ domain $(\Delta \mathrm{B})$ caused only a slight reduction in RN A-binding activity (to $75 \%$ of wild-type levels). In contrast, del etion of either the core $\mathrm{KH}$ domain $(\Delta \mathrm{D})$ or the carboxy-terminal region $(\Delta \mathrm{A})$ resulted in severe loss of RNA-binding activity, demonstrating that both of these regions are essential for maximal RN A-binding activity. Consistent with this observation, $\Delta \mathrm{C}$, which contains the $\mathrm{KH}$ domain but not the carboxy-terminal region, and $\Delta \mathrm{E}$, which contains the carboxy-terminal region alone, exhibit no RN A-binding activity in this assay. In an attempt to further define the sequences in the carboxy-terminal region required for RNA binding, two additional truncated proteins, $\Delta \mathrm{F}$ and $\Delta G$, were tested. N either of these proteins shows si gnificant RN A-binding activity. We conclude that both the $\mathrm{KH}$ domain and sequences in the carboxy-terminal region are essential for the RNA-binding activity of $\mathrm{pX}$ qua ${ }^{357}$. Examination of the carboxy-terminal sequence, however, does not reveal the presence of any previously described RN A-binding motif.

\section{pXqua can form homodimers}

How is it possible for pXqua, with only one $\mathrm{KH}$ domain, to bind RNA, whereas other KH proteins such as hnRN P $\mathrm{K}$ and FM RI need multiple KH motifs? One possibility is that two or more pXqua monomers might physically interact, thus al lowing multiple $\mathrm{KH}$ domains to cooperate in RNA binding. We therefore tested the ability of pXqua ${ }^{357}$ monomers to physically interact, using two different experimental approaches: first, coimmunoprecipitation (Fig. 3A) and, second, binding reactions using bacterial glutathione S-transferase (GST) fusi on proteins (Fig. 3B). For immunoprecipitation experiments, synthetic mRN As encoding a hemaggl utinin (HA) epitopetagged version of pXqua, pHA-Xqua ${ }^{357}$ and $\mathrm{pXqua}^{357}$ (with no HA tag) were cotranslated in a reticulocyte lysate (Fig. 3A, lane 5). Immunoprecipitation using an anti$\mathrm{HA}$ antibody resulted in the precipitation of $\mathrm{pHA}-$ $\mathrm{Xqua}^{357}$ and the coprecipitation of $\mathrm{pXqua}^{357}$ (Fig. 3A, lane 8), indicating that $\mathrm{pHA}-\mathrm{Xqua}^{357}$ and $\mathrm{pXqua}^{357}$ monomers are physically associated. Control immunoprecipitation of translations containing pXqua ${ }^{357}$ alone did not result in a detectable product (lane 7). Furthermore, when Anti-HA immunoprecipitations were performed on the cotranslation of $\mathrm{pHA}-\mathrm{Xqua}^{357}$ and an irrelevant protein (pFR), only $\mathrm{pHA}-\mathrm{Xqua}^{357}$ was detected (lanes 4 and 6). These immunoprecipitation results were confirmed using GST-Xqua protein binding experiments. Purified GST or GST -Xqua was immobilized on glutathione-Sepharose and then incubated with ${ }^{35} \mathrm{~S}-\mathrm{la}-$ beled pXqua ${ }^{357}$ or the control $\mathrm{KH}$ domain protein hnRNP K. After washing, the bound proteins were analyzed by SDS-PAGE. As shown in Figure 3B, labeled pXqua ${ }^{357}$ binds to the GST-Xqua fusion protein but not to GST alone. As expected, the hnRNP K control protein does not bind to either GST or GST-Xqua. Overall, these results demonstrate that $p \mathrm{Xqua}^{357}$ monomers are capable of forming physical complexes. The simplest interpretation is that two pXqua monomers interact to form a homodimer, but these experiments do not 

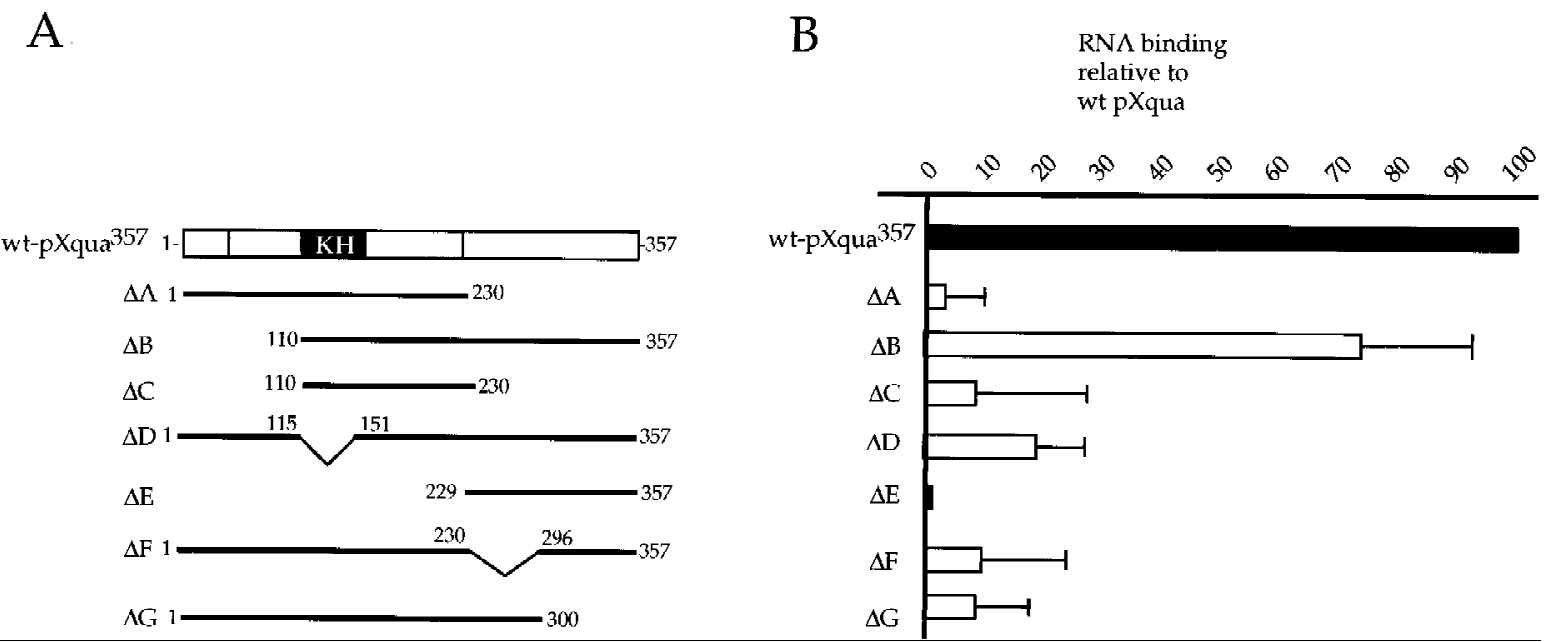

Figure 2. The $\mathrm{KH}$ motif and the carboxy-terminal region of pXqua are required for RNA binding. (A) Schematic representation of $\mathrm{pXqua}{ }^{357}$ and the truncated $\mathrm{pXqua}{ }^{357}-\Delta$ proteins. (B) ${ }^{35} \mathrm{~S}$-labeled, pXqua- $\Delta$ proteins were produced by in vitro translation of synthetic mRNA and assayed for RNA binding to total embryonic RNA-agarose at $100 \mathrm{~mm} \mathrm{NaCl}$. Bound proteins were resolved on $12.5 \%$ SDS-PAGE, visualized by fluorography, and quantitated using N ational Institutes of Heath (NIH) image software. The histogram shows relative RNA-binding activities of the different truncated pXqua- $\Delta$ proteins averaged from four separate experiments.

exclude the possi bility of oligomeric complexes containing more than two pXqua monomers.

pXqua ${ }^{357}$ is both cytoplasmic and nuclear

A role for $\mathrm{KH}$ domain proteins has been suggested at many levels of RNA metabolism from premRNA processing to translational regulation (Gibson et al. 1993). To obtain some information concerning the possible function of $\mathrm{pXqua}{ }^{357}$, we examined its subcellular location using the well-characterized Xenopus oocyte expression system. Numerous experiments have demonstrated that oocytes translate mi croinjected mRN As and faithfully compartmentalize the proteins to the correct subcellular location (Colman 1984). Synthetic capped mRN A encoding pXqua ${ }^{357}$, or control sequences encoding cytoplasmic EF-1 $\alpha$ (Krieg et al. 1989) or nuclear XMax (Tonissen and Krieg 1994), were microinjected into Xenopus oocytes. The results of these experiments (Fig. 4) show that pXqua ${ }^{357}$ is located in both the cytosolic and nuclear compartments. In each of 10 separate injection experiments, $\sim 60 \%$ of the pXqua ${ }^{357}$ is cytoplasmic, whereas $40 \%$ resides in the nucleus. Examination of controls indicates that $91 \%$ of the total $\mathrm{EF}-1 \alpha$ protein is in the cytoplasmic fraction, whereas $80 \%$ of the XM ax protein is translocated to the nucleus. Because the oocyte nucl eus represents $4 \%$ of the volume of the whole cell, pXqua is concentrated $\sim 10$-fold in the nucleus, relative to a random distribution. The same nuclear/cytoplasmic ratio is observed in each experiment, independent of the overall level of pXqua expression in the oocyte (data not shown), suggesting that its subcellular distribution is regulated. These experiments suggest that pXqua ${ }^{357}$ may have a biological function in both the nuclear and cytoplasmic compartments.
The carboxy-terminal regi on of pXqua is essential for translocation to the nucleus

$\mathrm{N}$ ucl ear import/ export is a dynamic process that is regulated tightly (Golbfarb and Michaud 1991; Powers and Forbes 1994), and therefore, it is of interest to determine which regions of pXqua ${ }^{357}$ are responsible for its subcelIular location. To investigate this, we examined the nuclear/cytoplasmic distribution of several pXqua deletion constructions (Fig. 5A). As shown in Figure 5B, deletion of the KH domain $(\Delta D)$ does not affect the nuclear/ cytoplasmic ratio, and deletion of amino-terminal residues $1-110 \quad(\Delta \mathrm{B})$ only moderately impairs the translocation to the nucleus. The most dramatic effect on the nuclear/cytoplasmic distribution is observed when the carboxyl terminus of the protein is deleted. In this case, virtually all of $\Delta \mathrm{A}$ is retained in the cytoplasm, approximately equivalent to the cytoplasmic control protein $\mathrm{EF}-1 \alpha$. Consistent with this observation, $\Delta \mathrm{E}$, which only contains carboxyl residues 229-357, behaves identically to the wild-type protein, indicating that the elements controlling nuclear import are found within this region. To further define the sequences responsible for nuclear translocation, $\Delta \mathrm{F}$ and $\Delta \mathrm{G}$ were al so expressed in oocytes. The truncated protein $\Delta \mathrm{F}$ showed a distribution equival ent to the wild-type $p X q u a$, whereas deletion of the last 60 amino acids $(\Delta G)$ caused a significant reduction of protein in the nucleus. We note, however, that $\Delta G$ was not as severely impaired as pXqua $\Delta \mathrm{A}$ in its ability to transl ocate to the nucleus, suggesting that perhaps not all of the sequences required for the correct nuclear/cytoplasmic distribution of $\mathrm{pXqua} \mathrm{a}^{357}$ are contained in the carboxy-terminal 60 amino aci ds. In no case do we find a significant increase in nuclear pXqua, a result that would be consistent with the deletion of a nuclear export or a cytoplasmic retention signal. 
A.

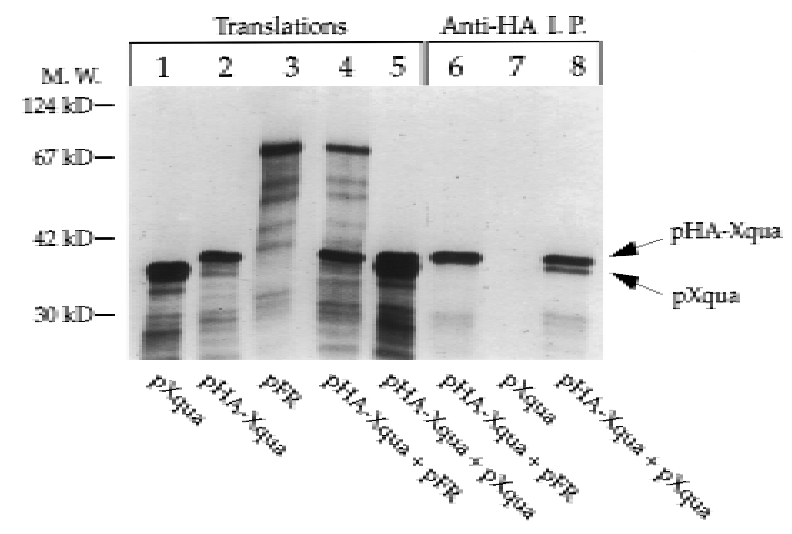

$\mathbf{B}$

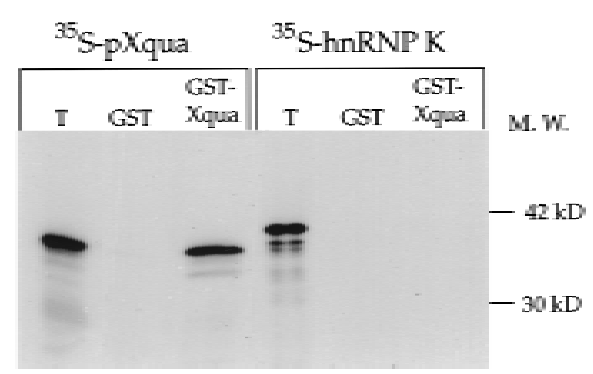

Figure 3. $p X q u a$ can form homodimers in vitro. (A) Synthetic mRN A encoding pXqua ${ }^{357}$ (lane 1); pHA-Xqua ${ }^{357}$, a HA epitopetagged version of pXqua ${ }^{357}$ (lane 2); or an irrelevant control protein, pFR (lane 3), was translated in reticulocyte lysates, resolved on SDS-PAGE, and visualized by fluorography. pXqua ${ }^{357}$ and $\mathrm{pHA}-\mathrm{Xqua}^{357}$ are distinguished from each other on the basis of the difference in their molecular mass (cf. lanes 1 and 2). To test for a physical interaction between pXqua monomers, pXqua ${ }^{357}$ and pHA-Xqua ${ }^{357}$ were cotranslated (lane 5), and pFR and $\mathrm{pHA}-\mathrm{Xqua}^{357}$ were also cotranslated as a control (lane 4). An equivalent portion of each reaction was immunoprecipitated with the anti-HA monoclonal antibody 12CA5, and precipitated proteins were resolved on 10\% SDS-PAGE and visualized by fluorography. The untagged $p X q u a$ was coprecipitated with pHA-Xqua (arrows) from the pXqua/pHA-Xqua cotranslation (lane 8), indicating that pXqua was bound to the HAXqua protein. pXqua ${ }^{357}$ al one was not precipitated (lane 7), nor was the control protein pFR coprecipitated from the pFR/pHAXqua cotranslation (lane 6). (B) pXqua dimerization demonstrated using GST -fusion protein binding assays. ${ }^{35} \mathrm{~S}$-label ed pXqua $^{357}$ or a control KH protein, hnRNP K, was incubated with either $2 \mu \mathrm{g}$ of GST al one or a GST-Xqua fusion protein, coupled to glutathione-Sepharose. The bound proteins were resolved on $10 \%$ SDS-PAGE and visualized by fluorography. The lane marked T represents $20 \%$ of the input translation.

Initial Xqua expression is localized to the dorsal blastopore lip

In mouse, expression of qkI mRNA is first detected at day 7.5 of gestation, and qk $^{\mathrm{e}}$ homozygous mutant embryos die by day 9 of gestation, indicating that early qk expression is essential (Justice and Bode 1988; Ebersole et al. 1996). The mutant embryos are smaller than normal and disorganized, but the exact nature of the defect is not clear. In Xenopus, embryonic expression of Xqua commences during early gastrulation (Zorn et al. 1997), suggesting that Xqua may play a role very early during development.

Using whole-mount in situ hybridization, we have examined the spatial pattern of Xqua expression in the frog embryo. As shown in Figure 6A, the earliest Xqua expression is detected in the chordamesoderm of the dorsal bl astopore lip of the midgastrula embryo (stage 11). This tissue, which is anal ogous to the node in the mouse embryo, is of particular interest because it differentiates into the notochord, has embryonic organizing activity, has neural inducing capability, and plays an integral role in the morphogenesis of the embryo (for review, see Hamburger 1988). To our knowledge, this is the first description of a RN A-binding protein that is localized to the blastopore lip. In late gastrula embryos (stage 13), high levels of Xqua expression are evident in the notochord, and the original expression domain expands to include the tissue surrounding the blastopore (Fig. 6B). In neurula embryos, Xqua expression is maintained in the notochord and the circumblastoporal region and now also extends to the paraxial mesoderm and the neuroectoderm (Fig. 6C-E). By the tailbud stage, Xqua is expressed in various mesodermal and neural tissues (Fig. $6 F, G)$. High levels of Xqua mRN A are found in the brain and the neural tube. Expression in the brain is restricted to the proliferative ventricular layer and the marginal

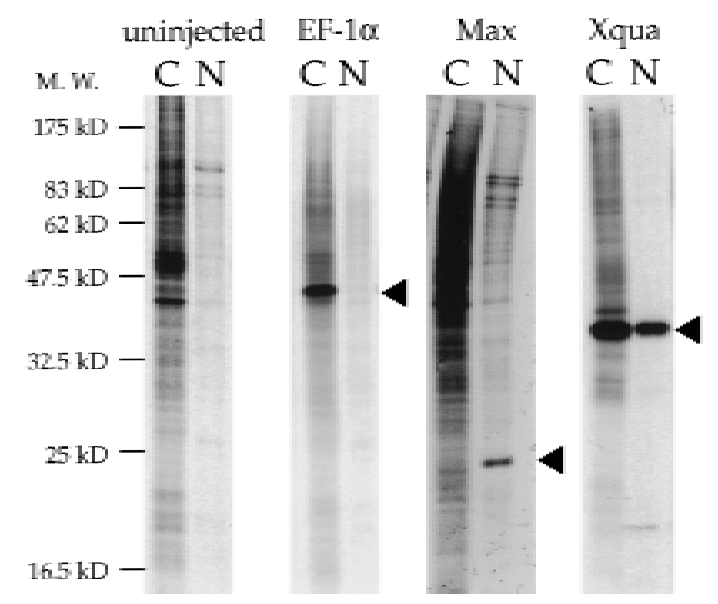

Figure 4. pXqua ${ }^{357}$ is both nuclear and cytosolic. The subcelIular distribution of $\mathrm{pXqua}{ }^{357}$ was determined using the Xenopus oocyte injection assay. Synthetic mRNAs encoding pXqua ${ }^{357}$ or control sequences encoding the cytoplasmic protein $\mathrm{EF}-1 \alpha$ or the nuclear protein XM ax were injected into the cytoplasm of Xenopus oocytes. Synthetic RN As were translated in the oocytes in the presence of $\left.{ }^{35} \mathrm{~S}\right] \mathrm{methionine.} \mathrm{Oocytes}$ were manually dissected into cytosolic (C) and nuclear (N) fractions. Protein extracts equival ent to one-fourth of each fraction from a single oocyte were resolved on SDS-PAGE and visualized by fluorography. Results of a representative experiment show that control proteins EF- $1 \alpha$ and XMax localize to the cytoplasmic and nuclear fractions, respectively. pXqua ${ }^{357}$ is present in both cytoplasmic and nuclear fractions. Arrowheads indicate the position of the relevant proteins. 
A

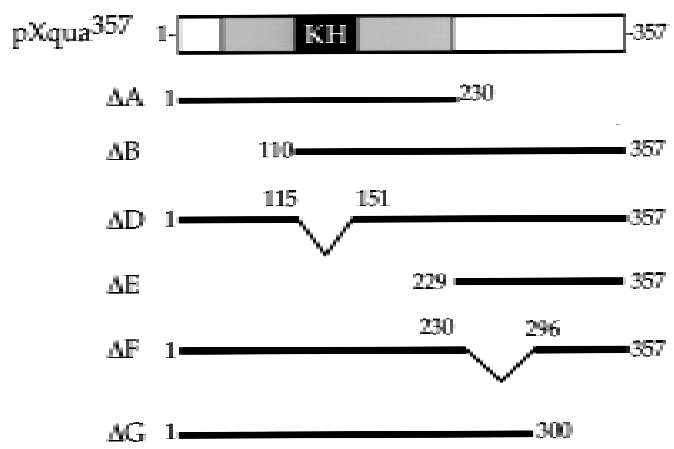

B Relatiwe amount of protein

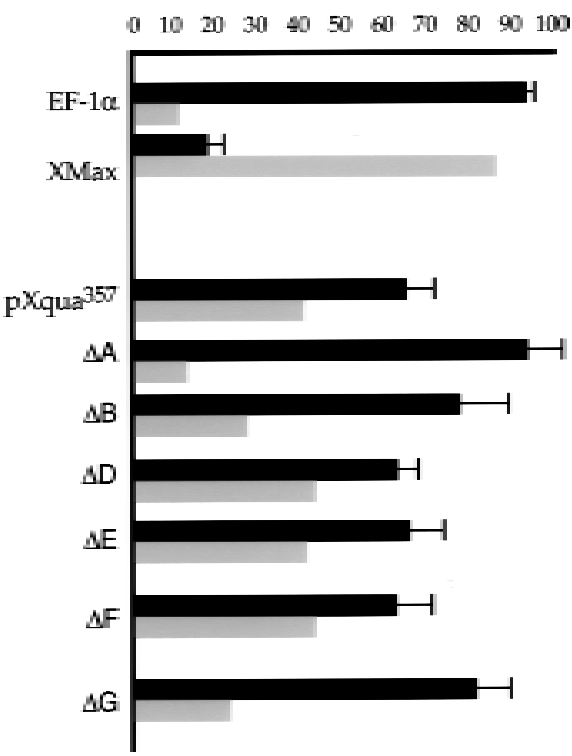

Figure 5. The carboxy-terminal region of $\mathrm{pXqua}{ }^{357}$ is required for translocation to the nucleus. The regions of $\mathrm{pXqua} \mathrm{a}^{357}$ that regulate its subcellular distribution were mapped by expression in Xenopus oocytes. (A) Schematic representation of pXqua ${ }^{357}$ and truncated pXqua ${ }^{357}-\Delta$ proteins. (B) Synthetic mRN As encoding $p X q u a^{357}$, the truncated pXqua proteins $\Delta A-\Delta G$, or control proteins EF1- $\alpha$ and $\mathrm{XM}$ ax were injected into the cytoplasm of Xenopus oocytes and translated in the presence of $\left[{ }^{35}\right.$ S]methionine. After manual enucleation, protein extracts from the cytosolic and nuclear fractions were resolved on SDS-PAGE and visualized by fluorography, and the relative proportion of the test protein in either fraction was determined using NIH image software. The histogram shows the relative amount of each test protein in the cytoplasmic (black) and nuclear (shaded) fraction, presented as a percentage of the total foreign protein expressed in the oocyte. The results were averaged from 5-15 separate injection experiments.

zone where active differentiation takes place (Fig. $6 \mathrm{H}$ ). High levels of Xqua are also detected in the branchial arches and in the developing heart. The tail blastema, which is known to maintain some embryonic organizer activity (Gont et al. 1993), al so expresses significant levels of Xqua mRN A. During this period of development, expression in the notochord and the somites declines, and by the hatched tadpole stage, Xqua expression is almost exclusively restricted to the head and heart (Fig. 6l).

O verexpression of wild-type and mutant Xqua mRNA disrupts anterior/axial development

Our expression studies show that Xqua is expressed in a variety of tissues of mesodermal and neural origin. To investigate the role of Xqua during devel opment of these tissues, we have overexpressed pXqua ${ }^{357}$ in the embryo by microinjection of synthetic $\mathrm{mRN} A$ and then examined embryos for developmental effects at the late tailbud stage. Microinjection of mRNA into two ventral blastomeres (2.5 ng/blastomere) targeted ectopic Xqua overexpression primarily to regions of the embryo that do not normally express Xqua, such as the non-neural ectoderm, the ventral mesoderm, or the endoderm. The distribution of the injected mRNA was monitored by coinjection of $\mathrm{mRN} A$ encoding green fluorescent protein
(GFP) (Zernicka-Goetz et al. 1996) or $\beta$-galactosi dase as a lineage marker (data not shown). Ectopic Xqua overexpression in the ventral region had no obvious effects on the development of the embryo (Table 1). However, targeting overexpression to regions of the embryo where Xqua is normally expressed, by microinjection into dorsal blastomeres (1.25-2.5 ng/blastomere), resulted in abnormal anterior development. At the highest dose of Xqua mRNA (2.5 ng/blastomere) over half of the embryos exhibit features of exaggerated dorsal-anterior development, including expanded hindbrains, reduced cement glands, enlarged eyes, and occasionally duplicated head structures (Fig. 7B; Table 1). Control injections of an equivalent amount of rRNA into dorsal blastomeres produced no observable phenotype (Fig. 7A; Table 1). These data indicate that when pXqua ${ }^{357}$ is expressed in tissues where it is not normally present, it has no obvious effects on development. In contrast, overexpression of pXqua ${ }^{357}$ in tissues where it is normally expressed produces devel opmental defects.

To further el uci date the role of pXqua in development, we wished to disrupt its function in the embryo. We chose to overexpress the $\Delta \mathrm{D}$ del etion mutant (Fig. 7C) that lacks the $\mathrm{KH}$ domain and exhibits severely impai red RNA-binding activity (Fig. 2). Because pXqua is able to form homodimers, the $\Delta \mathrm{D}$ mutant should interact with endogenous pXqua and inhibit the normal biochemical 


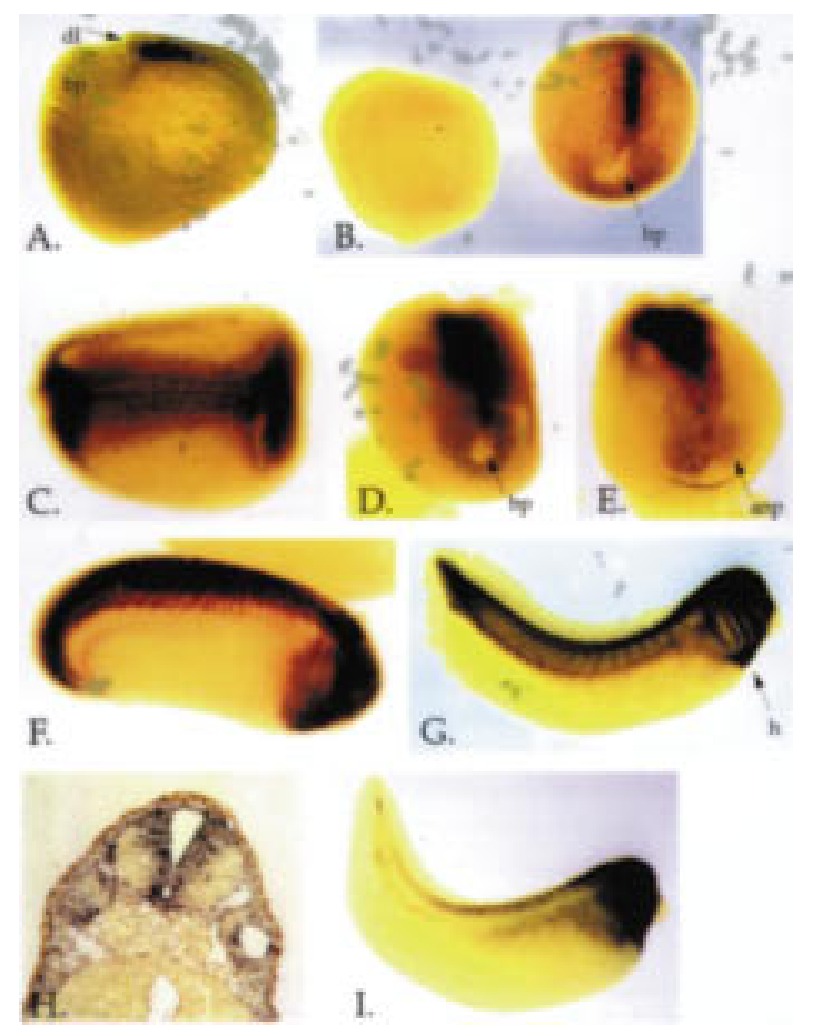

Figure 6. Embryonic expression of Xqua mRNA. Wholemount in situ hybridization using an RN A probe specific to the 5-kb embryonic form of Xqua. (A) Lateral view of a stage 11 gastrula embryo shows that transcripts are first detected in the chordamesoderm of the dorsal blastopore lip. (B) By late gastrula, Xqua is strongly expressed in the notochord with weak expression in the circumblastoporal region $(B$, embryo on the right, dorsal view). Embryos hybridized with sense strand control probes ( $B$, embryo on the left) show no staining. In neurula embryos (stage 18) (C, dorsal view; D, posterior view; E, anterior view), the expression domain has expanded to include the notochord, paraxial mesoderm, circumblastoporal region, and the neural plate. In tailbud embryos (stages 24-30) (F,G), Xqua is strongly expressed in the brain and neural tube, the developing heart, tail blastema, and branchial arches. (G) By late tailbud (stage 30), the expression in the notochord and somites is declining. $(\mathrm{H})$ Cross sections through the head of the stage 30 whole-mount embryo show that expression in the brain is largely restricted to the ventricular and marginal zones and the floor plate. (I) Later in development at hatched tadpole stage, Xqua expression is almost exclusively in the head and heart. (anp) Anterior neural plate; (bp) blastopore; (dl) dorsal lip; (h) heart; $(n)$ notochord.

function. To validate the use of $\Delta D$ as a dominant interfering agent, we have carried out two sets of experiments: the first demonstrating that $\Delta \mathrm{D}$ is able to dimerize with wild-type pXqua (Fig. 7D) and the second demonstrating that $\Delta \mathrm{D} / \mathrm{pX}$ qua heterodimers exhibit impaired RNA-binding activity (Fig. 7E). The protein binding experiments presented in Figure 7D show that $\Delta D$ is able to bind to GST-Xqua at levels equivalent to wildtype $\mathrm{pXqua}$, strongly suggesting that $\Delta \mathrm{D}$ will form het- erodi mers with endogenous $\mathrm{pXqua}$ in the embryo. Thein vitro RNA-binding assays presented in Figure 7E show that a fivefold excess of $\Delta D$ over wild-type $p X q u a^{357}$ reduces RNA binding to just $35 \%$ of control levels. We estimate that our overexpression protocol will result in at least a 100 -fold excess of $\Delta D$ over endogenous $p X q u a$ (based on relative RNA levels). Thus, overexpression of $\Delta \mathrm{D}$ in the embryo should effectively inhibit endogenous pXqua function, by interfering with the protein's ability to bind to its in vivo target RNA.

Synthetic mRNA encoding $\triangle D$ was microinjected into either the dorsal or ventral equatorial region at the fourcell stage, and embryos wereall owed to devel op until the late tailbud stage. Dorsal overexpression of $\Delta \mathrm{D}$ resulted in a dose-dependent deletion of anterior/axial structures. The phenotype ranged from microcephaly and acephaly at lower doses (0.5-1.25 ng/blastomere) to loss of the entire anterior half of the embryo at the highest dose (2.5 ng/blastomere) (Fig. 7F-I; Table 1). Spina bifida was al so frequently observed in cases showing severe anterior truncation. Overexpression of $\Delta D$ in ventral regions resulted in about half of the embryos having tail defects, but otherwise the morphology was normal . Lineage tracing, using coinjected GFP of $\beta$-galactosi dase mRN A, indicates that tail defects only occur when the majority of injected mRNA is localized to the posterior region including the ventral circumblastoporal tissue and the tail blastema (Fig. 7l), both of which normally express Xqua (Fig. 6B,D,F,G). In these cases we observe a disruption of blastopore closure. When the majority of the injected $\Delta \mathrm{D}$ $\mathrm{mRNA}$ is localized to regions of the embryo that do not normally express Xqua, such as the gut or ectoderm, the embryos develop normally. We therefore conclude that the $\Delta \mathrm{D}$ effects are specific to cells that normal ly express Xqua.

We have examined embryos overexpressing pXqua ${ }^{357}$ and $\Delta \mathrm{D}$ by histology and by whole-mount immunostaining using antibody markers to detect neural tissue, notochord, and somites. Histological sections and immunostaining show that in control embryos, the anterior end of the notochord usual ly terminates in a hook structure just behind the forebrain (Fig. 8A,G). Dorsal overexpression of Xqua results in an anterior extension of the notochord, in many cases until it contacts the ventral pharyngeal endoderm (Fig. 8B). This enhanced development of the anterior chordamesoderm is often accompanied by a disruption in the overlying neural tissue with the loss of forebrain features and a single expanded midbrain/ hindbrain vesi cle (Fig. 8B,H). In cases where Xqua overexpression caused a duplication of anterior head structures such as cement gl ands or eyes, immunostaining shows a duplication or forking of the notochord. In a few cases, as many as three notochords can be seen lying side by side (Fig. 8J). In contrast, dorsal overexpression of the $\Delta \mathrm{D}$ mutant has the opposite effect to overexpression of wild-type Xqua and caused a deletion of anterior structures. In microcephalic and acephalic embryos resulting from overexpression of $\Delta D$ at moderate levels (0.5-1.25 ng/blastomere), the anterior notochord is truncated, and this is accompanied by a loss of forebrain and 
Table 1. Summary of phenotypes resulting from Xqua and $\triangle \mathrm{D}$ mRNA microinjections

\begin{tabular}{|c|c|c|c|c|c|c|c|c|}
\hline $\begin{array}{l}\text { RN A } \\
\text { injected }\end{array}$ & $\begin{array}{l}\text { Location } \\
\text { (ng/blastomere) }^{a}\end{array}$ & $\begin{array}{c}\text { Number of } \\
\text { embryos }\end{array}$ & $\begin{array}{c}\text { Exaggerated } \\
\text { anterior } \\
\text { development } \\
(\%)\end{array}$ & $\begin{array}{c}\text { Microcephalic } \\
(\%)\end{array}$ & $\begin{array}{l}\text { Acephalic } \\
(\%)\end{array}$ & $\begin{array}{c}\text { Severe } \\
\text { anterior } \\
\text { truncation } \\
(\%)\end{array}$ & $\begin{array}{c}\text { Tail } \\
\text { defects } \\
(\%)\end{array}$ & $\begin{array}{c}\text { N ormal } \\
\text { devel opment } \\
(\%)\end{array}$ \\
\hline rRNA & dorsal $(2.5 \mathrm{ng})$ & 90 & 0 & 1 & 0 & 0 & 0 & 99 \\
\hline rRNA & ventral $(2.5 \mathrm{ng})$ & 30 & 0 & 0 & 0 & 0 & 3 & 97 \\
\hline Xqua & dorsal (1.25 ng) & 18 & 11 & 0 & 0 & 0 & 0 & 89 \\
\hline Xqua & dorsal $(2.5 \mathrm{ng})$ & 50 & 54 & 0 & 0 & 0 & 0 & 46 \\
\hline Xqua & ventral $(2.5 \mathrm{ng})$ & 25 & 0 & 0 & 0 & 0 & 12 & 88 \\
\hline$\Delta \mathrm{D}$ & dorsal $(0.5 \mathrm{ng})$ & 31 & 0 & 35 & 0 & 0 & 0 & 65 \\
\hline$\Delta \mathrm{D}$ & dorsal (1.25 ng) & 20 & 0 & 32 & 56 & 2 & 0 & 2 \\
\hline$\Delta \mathrm{D}$ & dorsal $(2.5 \mathrm{ng})$ & 66 & 0 & 27 & 24 & 49 & 0 & 0 \\
\hline$\Delta \mathrm{D}$ & ventral (2.5 ng) & 51 & 0 & 8 & 4 & 0 & $57^{b}$ & 31 \\
\hline
\end{tabular}

${ }^{a}$ mRN A was injected into the equatorial region of either the two dorsal or the two ventral blastomeres at the four-cell stage.

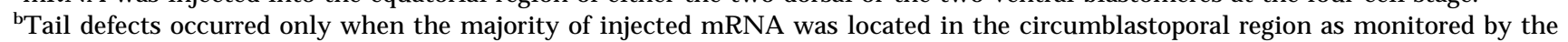
coinjection of GFP or $\beta$-gal actosidase mRN A as a lineage marker (see Fig. 71).

facial structures (Fig. 8C). Histology and immunostaining of the more severe anterior truncations resulting from high-level $\Delta \mathrm{D}$ overexpression $(2.5 \mathrm{ng} /$ blastomere) show a complete loss of all head structures and a total absence of the anterior portion of the notochord as well as a dramatic reduction in neural and somitic tissue (Fig. $8 \mathrm{D}, \mathrm{K}-\mathrm{M})$. In most cases a small amount of posterior notochord tissue is observed in the tip of the tail, which is split in two as a result of spina bifida (Fig. 8M ). Lineage tracing confirmed that the residual notochord developed in the posterior region of the axial mesoderm that received a relatively low dose of $\triangle D$ mRNA (data not shown).

\section{Xqua is essential for notochord differentiation}

Because Xqua is normally expressed in a number of neural and mesodermal tissues, it is likely that overexpression of Xqua or $\Delta \mathrm{D}$ influences the development of each of these tissues directly. However, many of the phenotypic effects that we observe are likely to result from disruption of the normal development of the chordamesoderm and its derivative, the notochord. In this case, impaired chordamesoderm devel opment could influence its neural inducing and embryonic patterning properties, thereby causing defects in neural tissue and other anterior structures. In practice, we expect chordamesoderm and notochord tissues to be particularly vulnerable in these overexpression studies because they are the earliest domains of Xqua expression in the embryo and levels of most injected mRN A decline rapidly after gastrulation (Vize et al. 1991). To simplify analysis, subsequent experiments have focused on the role of Xqua in notochord development.

To avoid possible secondary effects that may occur in whole-embryo studies, the effects of Xqua and $\Delta D$ overexpression on notochord differentiation have been examined in dorsal mesoderm explants. In these experiments, Xqua or $\triangle \mathrm{D}$ mRN A was microinjected into dorsal blastomeres at the four-cell stage $(2.5 \mathrm{ng} /$ blastomere). At early gastrula, the dorsal half of the mesoderm, which contains the prospective notochord and somites, was dissected from the embryo, and two of these dorsal mesoderm pieces were combined and cultured in a saline soIution. The results of a typical experiment are presented in Figure 9. Because chordamesoderm undergoes convergent extension cell movements, the external morphology of the explants provides some indication of the amount of notochord that has differentiated (Fig. $9 C, E, G)$. Dorsal marginal zone explants from embryos overexpressing Xqua (Fig. 9E) consistently produce more extended structures than control explants injected with rRNA (Fig. 9C). This result is consistent with the extended notochords observed in whole embryos overexpressing Xqua. Conversely, explants from embryos injected with $\triangle \mathrm{D}$ mRN A (Fig. 9G) showed less elongation compared with control explants. When sibling control embryos had reached tail bud stage, explants were fixed, sectioned, and immunostained for the presence of notochord (black) and somite (red). Twelve independent explants from two separate injection experiments produced consistent results, and a representative section through a typical explant of each type is shown (Fig. 9D,F,H). Explants overexpressing Xqua were more elongated but showed only a slight increase in the total amount of notochord tissue, $\sim 10 \%$ more notochord tissue than in control explants (Fig. 9F). It is possible that the apparent increase in notochord tissue may be owing to enhanced morphogenic movements. In contrast, in all 12 cases, much less notochord tissue differentiated in explants overexpressing $\triangle \mathrm{D}$ mRNA, relative to rRNA-injected controls (Fig. 9, cf. D and H). $\Delta$ D overexpressing explants had $\sim 10 \%$ of the amount of notochord found in control explants. In general, somite differentiation was unaffected in these experiments. To demonstrate that $\Delta D$ overexpression is inhibiting notochord development by specifically interfering with Xqua function, we have performed rescue experiments. In every case (six explants), notochord development was significantly rescued in explants coexpressing Xqua and $\Delta \mathrm{D}$ (at a 1:1 mRN A ratio) 

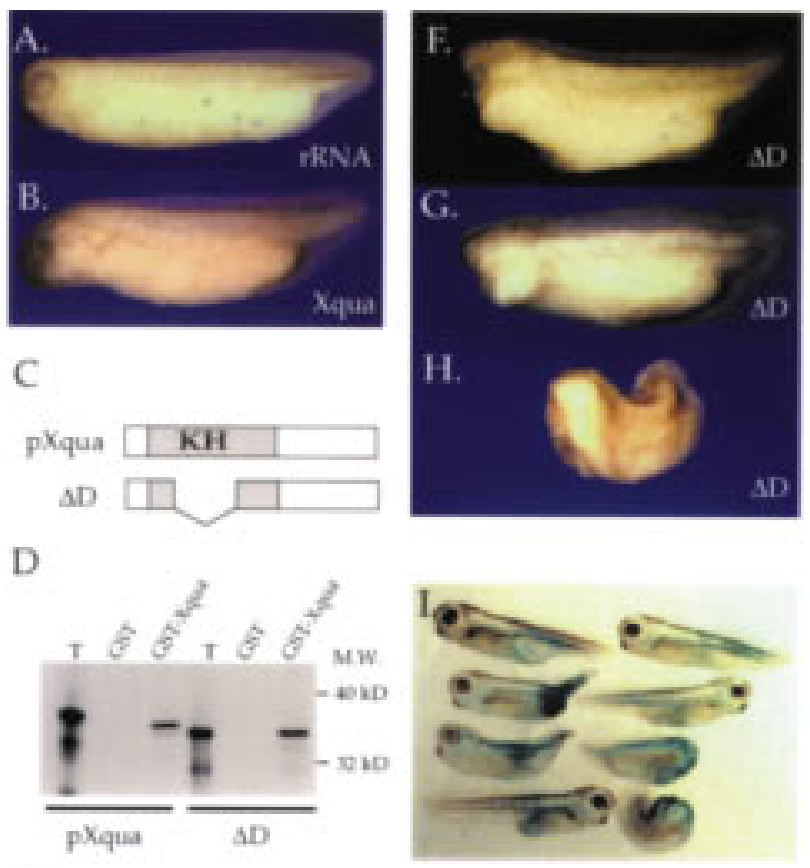

E

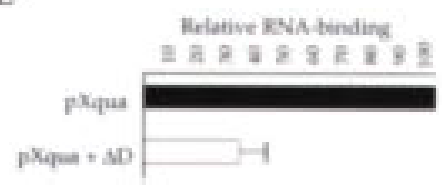

Figure 7. Overexpression of Xqua and $\Delta D$ causes defects in anterior development. Synthetic mRN A encoding either pXqua ${ }^{357}$, the truncated pXqua protein $\Delta \mathrm{D}$ (which lacks the $\mathrm{KH}$ motif), or control rRN A was overexpressed in embryos by microinjection into the equatorial region of each of the two dorsal blastomeres at the four-cell stage. (A) Overexpression of rRN A ( $2.5 \mathrm{ng} / \mathrm{blas}$ tomere) has no effect on development. (B) Dorsal injection of Xqua mRNA ( $2.5 \mathrm{ng} /$ blastomere) resulted in exaggerated anterior development including elongation of the hindbrain region and reduced cement glands. (C) Schematic representation of pXqua ${ }^{357}$ and $\Delta \mathrm{D}$ proteins. Representative embryos illustrating the phenotypes are shown. (D) The $\Delta D$ protein is able to form dimers with wild-type $p X q u a .{ }^{35} \mathrm{~S}$-Labeled $p X q u a^{357}$ or $\Delta \mathrm{D}$ was incubated with either $2 \mu \mathrm{g}$ of GST al one or a GST-Xqua fusion protein coupled to glutathione-Sepharose. The bound proteins were resolved on $12 \%$ SDS-PAGE and visualized by fluorography. The lane marked T represents $20 \%$ of the input translation. (E) $\Delta \mathrm{D} / \mathrm{pX}$ qua heterodimers have reduced RN A-binding activity. ${ }^{35} \mathrm{~S}$-Labeled $p X q u a$ was synthesized in vitro, either al one or by cotranslation with a fivefold excess of $\triangle D$ mRN A. The RN Abinding activity of the wild-type pXqua, or the $\Delta \mathrm{D} / \mathrm{pX}$ qua mixture, was assayed by binding to poly(G)-agarose. Bound proteins were resolved on $12.5 \%$ SDS-PAGE and quantitated by Phosphorlmager analysis. The results, averaged from three separate experiments, are presented as a histograph that indicates that $\Delta D / p X q u a$ heterodimers exhibit impaired RN A binding. Dorsal overexpression of $\Delta D$ resulted in a dose-dependent deletion of anterior structures ranging from (F) microcephalic and (G) acephal ic embryos at low mRN A levels ( $0.5-1.25 \mathrm{ng} /$ blastomere) to $(\mathrm{H})$ severe anterior-half truncations at higher doses $(2.5 \mathrm{ng} / \mathrm{blas}-$ tomere). (I) Lineage tracing of embryos coinjected with a high dose of $\Delta D$ and $\beta$-galactosidase mRN A shows that the phenotypic effects of $\Delta D$ are specific to dorsal tissues. The tissue expressing the injected mRNA is stained blue. relative to explants overexpressing $\Delta \mathrm{D}$ alone (Fig. 9, cf. $D, H$, and I). Rescue explants had on average $50 \%$ of the amount of notochord found in uninjected control explants, up from only $10 \%$ found in $\Delta D$ explants. Similar rescue experiments using whol e embryos were inconclu-
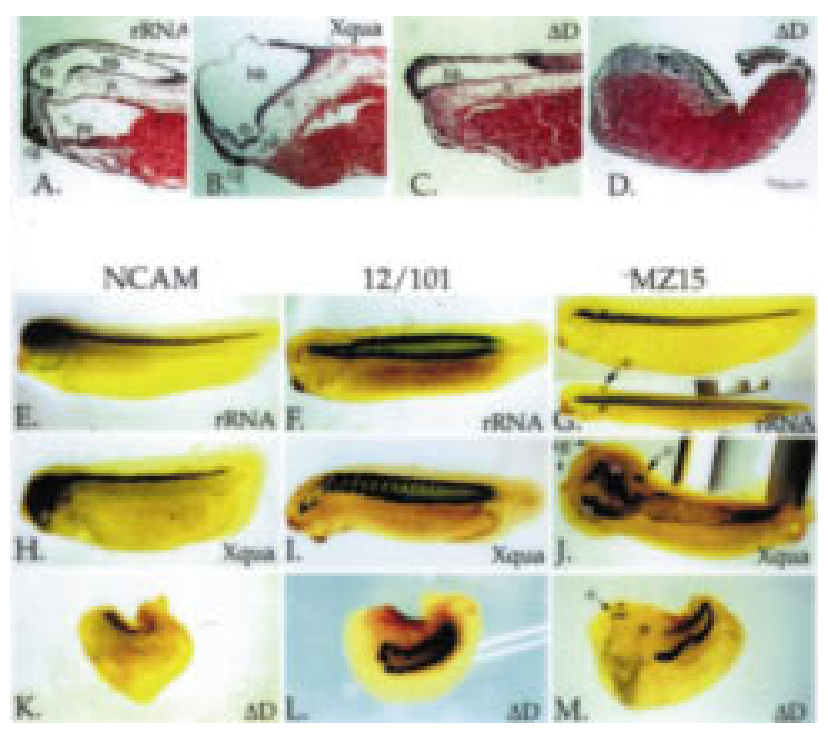

Figure 8. Histological and immunostaining analysis of abnormal development resulting from dorsal $X$ qua and $\Delta D$ overexpression. Control rRNA, Xqua, or $\Delta \mathrm{D}$ was microinjected into the equatorial region of each of the two dorsal blastomeres at the four-cell stage $(2.5 \mathrm{ng} /$ blastomere, except embryo in C that was $1.25 \mathrm{ng} /$ blastomere). Representative embryos were examined by (A-D) histological sectioning and hemotoxylin/eosin staining or by whole-mount immunostaining with the monoclonal antibodies $(E, H, K)$ Anti-N CAM for neural tissue, $(F, I, L)$ $12 / 101$ for somites, and (G,J,M) MZ15 for notochord. Control embryos injected with rRN A are shown in $A, E, F$, and G; embryos overexpressing Xqua are shown in $\mathrm{B}, \mathrm{H}, \mathrm{I}$, and $\mathrm{J}$; and embryos overexpressing $\Delta \mathrm{D}$ are shown in $\mathrm{C}, \mathrm{D}, \mathrm{K}, \mathrm{L}$, and $\mathrm{M}$. In all panels, anterior is left and a lateral view is shown, except the bottom image in $G$ and J, which are dorsal views. $(A, G)$ In control embryos the notochord ends anteriorly behind the forebrain. (B) Dorsal injection of Xqua results in an elongation of the notochord into the head until it reaches the ventral pharyngeal endoderm and $(\mathrm{B}, \mathrm{H})$ a reduction in forebrain and anterior facial structures with an enlarged hindbrain vesicle. (J, dorsal view) Xqua overexpression occasionally results in duplications of the notochord and facial structures; notice two notochords lying side by side and two cement glands. (I) The somites are relatively normal in Xqua overexpressing embryos. (C) Histological section of embryos with a low-level overexpression of $\Delta \mathrm{D}(1.25 \mathrm{ng} /$ blastomere) shows a truncation of the anterior notochord with a loss of forebrain and anterior head structures. $(\mathrm{D}, \mathrm{K}, \mathrm{L}, \mathrm{M}) \mathrm{High}$-level overexpression of $\Delta \mathrm{D}$ ( $2.5 \mathrm{ng} /$ blastomere) causes a complete truncation of the anterior half of the embryos. (K) These embryos exhibit little neural tissue, $(L)$ reduced somites, and (M) only small amounts of posterior notochord tissue. $\Delta D$ embryos show a high frequency of spina bifida resulting in a splitting of the residual notochord tissue; notice the duplicated notochord in the tail. (cg) Cement gland; (fb) forebrain; (hb) hindbrain; (n) notochord; (o) otic vesicle; (pe) pharyngeal endoderm. 


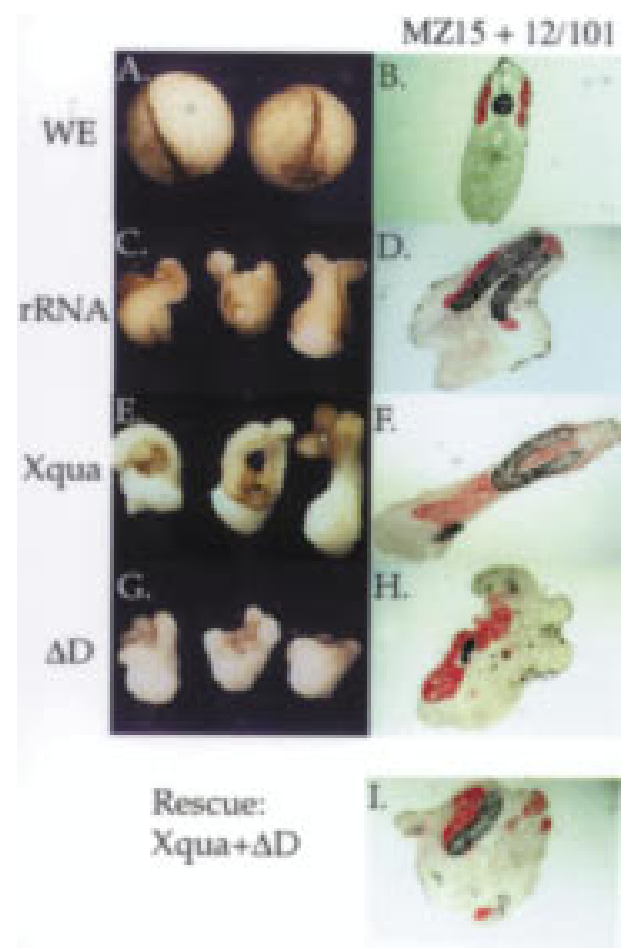

Figure 9. Overexpression of the $p X q u a$ mutant $\Delta D$ inhibits notochord differentiation. rRN A (2.5 ng), Xqua, or $\triangle \mathrm{D}$ mRN A was injected into each of the two dorsal blastomeres at the four-cell stage. Dorsal mesoderm explants containing presumptive notochord and somite tissue were dissected from injected embryos at early gastrula (stage 10-10.5) and cultured in isolation to examine notochord differentiation directly. (A,C,E,G) External morphology of the explants is shown when sibling embryos (WE) reached early neurula stage. $(B, D, F, H, I)$. At later tailbud stage, explants were fixed, sectioned, and immunostained with MZ15 for notochord (black) and 12/101 for somite (red). From a total of 12 explant experiments, a section through a typical explant is presented. (C) Control rRN A explants exhibit considerable elongation resulting from convergent extention movements of the devel oping notochord, and (D) immunostaining of control explants shows a substantial amount of notochord and somite tissue. (E) Xqua overexpressing explants exhibit more dramatic morphological elongation and (F) contain moderately more notochord and somite tissue than controls (cf. amount of unstained tissue to that in D). (G) Explants overexpressing $\Delta \mathrm{D}$ exhibit very little morphological el ongation compared with controls (cf. to $\mathrm{C}$ ) and $(\mathrm{H})$ show dramatically less notochord tissue but little change in the amount of somite tissue. (I) Inhibition of notochord differentiation owing to $\Delta D$ overexpression is rescued by coinjection of an equal amount of synthetic Xqua mRN A ( 5 ng of $\Delta D+5$ ng of Xqua) (cf. amount of notochord in I to $H$ and $D$ ), indicating that the biological effects of $\Delta D$ overexpression are specific to the Xqua pathway.

sive owing to the large amount of mRNA required (at least $10 \mathrm{ng}$ ) that caused nonspecific gastrulation defects. As a result of the Xqua and $\Delta \mathrm{D}$ overexpression experiments, we conclude that normal Xqua function is essential for notochord differentiation.
Xqua is involved in early stages of notochord specification

Our explant experiments show that Xqua function is essential for notochord development. To learn more about this effect, we have investigated whether Xqua is required for terminal differentiation of the notochord or whether it is functioning during specification. Because Xqua is expressed early in the prenotochord tissue during gastrulation, we have looked at the effect of $\Delta D$ overexpression on early chordamesoderm and notochord specific markers. Embryos were injected in the two dorsal bl astomeres at the four-cell stage with $2.5 \mathrm{ng} /$ blastomere mRN A encoding the dominant inhibitor $\triangle \mathrm{D}$ or with $\Delta \mathrm{D}$ plus $\beta$-gal actosi dase mRN A as a lineage tracer. Previous experiments have demonstrated that this dose is sufficient to strongly inhibit notochord differentiation (Figs. $7 \mathrm{H}, 8 \mathrm{M}$, and $9 \mathrm{H}$ ). At the gastrula stage, injected embryos were assayed for the following transcripts: (1) Xnot-2 (Gont et al. 1993), which marks the early notochord; (2) Xbra (Smith et al. 1991), Xenopus bracyhury, which is expressed in the notochord in late gastrula and is panmesodermal in early gastrula; and (3) gsc (Cho et al. 1991), which marks the dorsal lip and the presumptive prechordal plate mesoderm. The first morphological effects of $\Delta \mathrm{D}$ overexpression are detected at the late gastrula stage when the embryos exhibit disrupted gastrulation and the blastopore does not close properly (Fig. 10, cf. A and D, morphology of control embryos, with B, C, and $\mathrm{E}$, experimental embryos). Analyis using in situ hybridization indicates that transcript levels for all three markers are severely down-regulated by $\Delta D$ overexpression. In particular, expression of Xnot-2 and Xbra is completely absent from the dorsal midline where the notochord would normally form (Fig. 10A-F). Residual Xnot-2 expression is often seen in two lateral patches. These apparently correlate with the two remnant notochords that are often observed at later stages in the tail of $\Delta \mathrm{D}$-injected embryos (Fig. 8M). Lineage tracing using $\beta$ gal actosidase activity (Fig. 10C,F,I,L) confirms that the effect is restricted to cells that express the dominantnegative $\Delta \mathrm{D}$. These results demonstrate that Xqua is acting very early during development of the chordamesoderm and that pXqua function is required for the accumulation of several essential mRNAs. Given the down-regulation of Xnot-2, Xbra, and gsc transcripts in embryos in which Xqua function has been disrupted, it is not surprsing that notochord devel opment is impaired in these embryos.

\section{Discussion}

\section{RNA-binding properties of pXqua}

Our experiments show that $\mathrm{pXqua}$, which contains a single KH motif, can bind RN A in vitro. This is al so true for S3 (Urlaub et al. 1995) and the GSG protein SAM 68 (Wong et al. 1992; Taylor and Shalloway 1994; Wang et al. 1995), which al so contain single KH motifs. However, most other $\mathrm{KH}$ proteins require the cooperation of multiple RNA-binding motifs for efficient RNA binding 

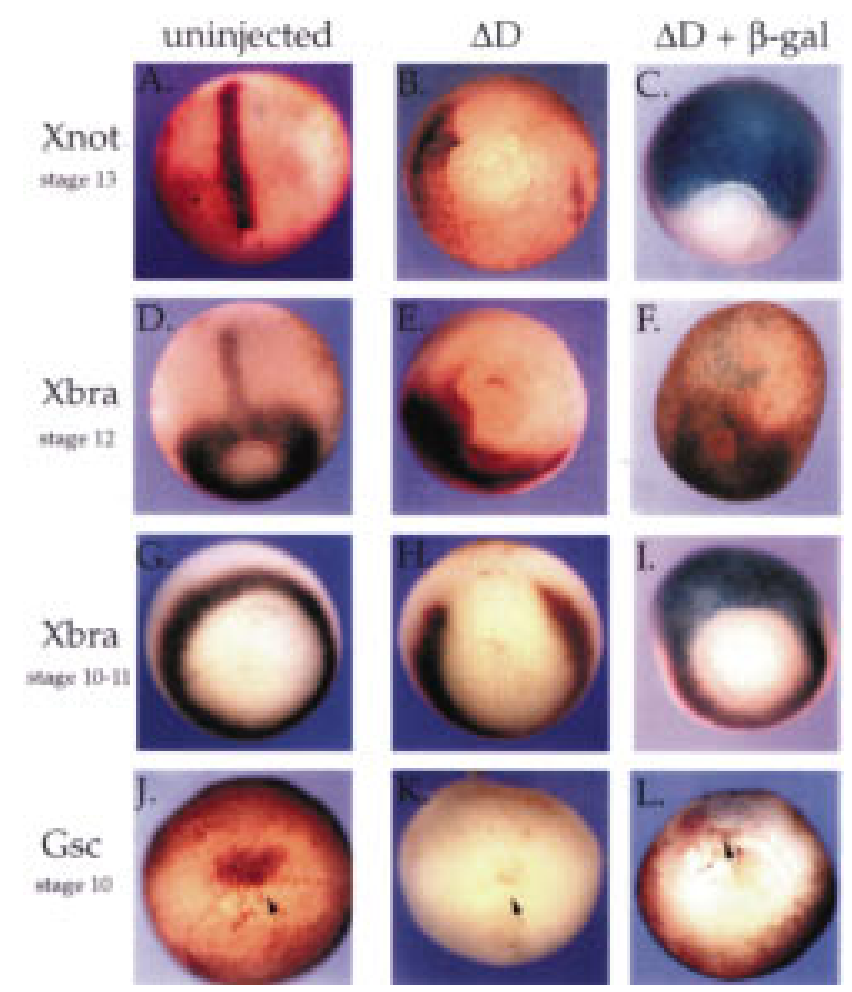

Figure 10. Inhibition of Xqua function results in down-regulation of early notochord marker mRN As. mRN A (2.5 ng) encoding the dominant-negative $\mathrm{pXqua}$ protein $\Delta \mathrm{D}$ or $\Delta \mathrm{D}$ plus $\beta$-galactosidase was microinjected into the equatorial region of each of the two dorsal blastomeres at the four-cell stage. The resulting embryos, together with uninjected control embryos, were fixed at gastrula stages and analyzed by whole-mount in situ hybridization for expression of early dorsal mesoderm and notochord mRNA markers: Xnot-2 (A-C), Xbra (D-I), and gsc $(\mathrm{J}-\mathrm{L})$. A rrows indicate the location of the dorsal lip in early stage embryos. In C, F, I, and L, embryos were stained with X-gal (blue) prior to in situ hybridization (purple/brown), to indicate the cells that received the $\Delta D$ mutant. Overexpression of $\Delta D$ in the dorsal mesoderm results in disruption of gastrulation and a loss of detectable Xnot-2, Xbra, and gsc transcripts in recipient cells.

(Siomi et al. 1994). Therefore, it was not entirely clear how proteins with a single KH motif could bind RN A. In pXqua the $\mathrm{KH}$ domain is essential but not sufficient for full RN A-binding activity, because the carboxyl terminus is also required. There are several possibilities to explain the necessity of the carboxy-terminal region. The carboxyl terminus may contain an RNA-binding motif that cooperates directly with the $\mathrm{KH}$ domain for RNA binding. This seems unlikely, however, because extensive sequence comparisons of the carboxy-terminal regi on have detected no known RN A-binding motifs. On the other hand, we have demonstrated that pXqua can homodimerize, and it is possible that this is an essential precondition for RNA binding. This argument is supported by the observation that addition of $\Delta D$ to $p X$ qua inhibits RNA binding, presumably owing to the forma- tion of $\Delta D / p X q u a$ heterodimers. Deletion of the carboxyl terminus of pXqua may remove or disrupt sequences essential for dimerization thereby inhibiting RNA-binding activity.

The proteins FMR1, FXR1, and FXR2, all of which have two KH motifs, can homo- and heterodi merize with each other (Zhang et al. 1995), al though it is not known whether this interaction is required for RN A binding. It has been proposed that GSG proteins may be involved in protein-protein interactions (Jones and Schedl 1995; Musco et al. 1996), and our pXqua studies provide the first demonstration of homodimerization in this class of protein. It is possible that homodimerization is a general feature of GSG proteins, explaining how they can effectively bind RN A with only one $\mathrm{KH}$ domain. If dimerizati on-dependent RN A binding is a general feature of GSG proteins, then, in addition to elements in the carboxyterminal regi on of $\mathrm{pXqua}$, it is reasonable to suggest that sequences within the conserved GSG domain might al so be involved in protein interactions. Structural analysis of the GSG-type KH domain predicts an extended loop region that is absent in typical $\mathrm{KH}$ motifs, and it is speculated that this loop may be involved in protein-protein interactions (Musco et al. 1996). The $\Delta \mathrm{D}$ mutant, in which the first part of the $\mathrm{KH}$ core domain is deleted, still dimerizes with $\mathrm{pXqua}$, indicating that this region is not essential for protein-protein interactions. The loop region that is conserved between GSG family members is left intact in the $\Delta D$ mutant and therefore remains a prime candi date for a dimerization motif. We are currently mapping the protein interaction domains of pXqua and investigating the relationship between dimerization and RNA binding.

\section{Subcellular distribution of quaking}

We have shown that pXqua is distributed between the nuclear and cytoplasmic compartments of the cell and that the nuclear localization signal (NLS) is contained within the last 60 amino acids of the protein. Examination of the carboxyl terminus does not reveal a recognizable N LS although the last 60 amino acids contain a concentration of basic residues that are often found in the NLS. In mouse, the 5-, 6-, and 7-kb qkI mRNAs generate the QK1-5, QK1-6 and QK1-7 proteins, respectively, which are identical except for the extreme carboxy-terminal sequences (Ebersole et al. 1996). Recent immunolocalization studies in mouse brain tissue using antibodies specific for each of the three distinct QK1 carboxy-terminal regions show that QK1-5 (equivalent to pXqua ${ }^{357}$ ) is detected in the nucleus and cytoplasm, whereas QK1-6 and QK1-7 are al most exclusively cytoplasmic (Hardy et al. 1996). These observations are consistent with our results; furthermore, it appears that the alternative carboxy-terminal regi ons regulate the subcellular location of the QK1 proteins. Because the last 60 amino acids of the mouse and Xenopus 5-kb quaking sequences are identical (Zorn et al. 1997), the NLS of pXqua ${ }^{357}$ (QK1-5) is likely to reside in the last 30 amino acid residues that are al ternatively spliced. It will be in- 
teresting to determine whether the different isoforms can heterodimerize and if so, what effect this has on their subcellular distribution and hence their function.

\section{Xqua is essential for notochord development}

The earliest embryonic expression of Xqua occurs in the chordamesoderm of the dorsal blastopore lip. This regi on of tissue, which is known as the organizer, is particularly interesting because it differentiates into the notochord, has neural-inducing activity, has a major role in embryonic patterning, and is responsible for the morphogenic movements of gastrulation. To our knowledge, this is the first example of an RNA-binding protein that is expressed in the vertebrate organizer regi on and its major derivative, the notochord. To date, expression of qkl mRN A in the chordamesoderm of the mouse embryo has not been reported, but expression studies on early embryos have been limited. Our experiments show that ectopic expression of Xqua does not cause notochord differentiation at ectopic locations, but it can enhance the development of notochord tissue, suggesting that Xqua is probably involved in the maintenance of the differentiation process rather than determination of notochord cell fate. Similar phenotypic effects, that is, increased notochord development and subsequent enlargement of the hindbrain, have been observed from overexpression of the Xnot-2 homeobox sequence, which is also normally expressed in the organizer and notochord (Gont et al. 1996). In our experiments, bl ocking endogenous Xqua function by overexpression of the dominant interfering Xqua protein, $\Delta D$, inhibits the differentiation of the notochord, demonstrating that Xqua is essential for this process. Furthermore, the neural inducing properties of the chordamesoderm/organizer are inhibited in these embryos, resulting in little or no anterior neural tissue. Phenotypically similar aneural embryos are observed when formation of the chordamesoderm/organizer is inhibited by UV irradiation of fertilized Xenopus eggs (for review, see Kao and Danilchik 1991). Analysis of early gene transcripts suggests that the phenotypic effects of $\Delta \mathrm{D}$ overexpression can be explained by a down-regulation of essential mRNAs such as Xnot-2, Xbra, and gsc and possibly many others. Based on comparisons to the mouse bracyhury mutation (Herrmann et al. 1990) and the zebrafish floating head (zebrafish Xnot) mutations (Talbot et al. 1995), down-regulation of Xbra and Xnot mRN As could largely account for the observed phenotype. Interestingly, some of the $\mathrm{qk}^{\mathrm{e}}$ embryonic lethal mutant mice have axial defects and failure of head development (Justice and Bode 1988), with a phenotype reminiscent of the Xenopus embryos resulting from overexpression of mutant $\Delta \mathrm{D}$ protein. These $\mathrm{qk}^{\mathrm{e}}$ phenotypes could be explained, by analogy with our results, if quaking also functions in mammals to maintain chordamesoderm development and its embryonic organizer activity.

The role of quaking in vertebrate development

Our overexpression experiments have focused on the role of pXqua in the development of the chordamesoderm and notochord. These tissues are the sites of earliest Xqua expression in the embryo and are therefore the most easily disrupted in overexpressi on studies. Whereas our experiments show that Xqua function is critical for notochord development, quaking is expressed in a number of different embryonic and adult ti ssues and is therefore likely to be required for the differentiation or development of many cell types. The later embryonic expression of Xqua in the head, heart, and somites is similar to the pattern of qkl expression observed in mouse embryos (Ebersole et al. 1996) and correlates well with the diminished head folds, disorganized somites, and malformed hearts observed in $\mathrm{qk}^{\mathrm{e}}$ mutant embryos (Justice and Bode 1988). The high levels of Xqua expression in the developing central nervous system, particularly in the proliferating and actively differentiating layers of the devel oping brain where the neuronal and oligodendrocytes ori ginate, are exactly where qkl expression is detected in the mouse neonatal brain (Ebersole et al. 1996) and are consistent with the myelination defects observed in $\mathrm{qk}^{\mathrm{v}}$ mice (Sidman et al . 1964; Samorajski et al . 1970). Recent immunostaining studies show a dramatic reduction of QK1 (equivalent to $\mathrm{pXqua}{ }^{357}$ ) protein levels in oligodendrocytes and Schwann cells of $\mathrm{qk}^{\vee}$ mutant mice, compared with wild-type mice (Hardy et al. 1996). The reduction of QK1 is directly correl ated with the dismyelination defect and suggests that lack of the QK1 protein, and hence lack of QK1 function, prevents proper differentiation of myel inating cells. This observation parallels our experimental results where inhibition of pXqua ${ }^{357}$ function by overexpression of pXqua mutants results in an inhibition of notochord differentiation.

Although more information is needed to define the bi ochemical function of quaking, available evidence suggests that it regulates expression of transcripts essential for differentiation of some cells. $\mathrm{KH}$ proteins have been implicated in a diversity of processes at all levels of RN A metabolism although in most cases their precise biochemical functions are unclear. Because pXqua is present in both cytoplasmic and nuclear components, we should consider a role for the protein in each compartment. Interestingly, some abnormalities in RNA metabolism have been observed in the neural tissue of $\mathrm{qk}^{\mathrm{v}}$ mutant mice. Proportions of particular alternatively spliced mRNA isoforms of myelin-associated glycoprotein, MAG (Fujita et al. 1988; Braun et al. 1990; Bartoszewicz et al. 1995), and myelin basic protein, MBP (Carnow et al. 1984), are altered in qk mice, whereas other mRNAs are unaffected. These observations are consistent with the experimental results indicating that blocking Xqua function prevents the accumulation of Xnot-2, Xbra, and gsc transcripts. The fact that levels of all three tested marker transcripts were reduced suggests that pXqua somehow regulates a number of different mRNAs. It is also possible that quaking may act more generally by regulating global mRN A levels in mesodermal and neural cells. Although the mechanism of action is unknown, available evidence suggests that quaking regulates mRNA stability, processing, or both and that 
blocking quaking function prevents specific mRNAs from accumulating to detectable levels.

\section{Materials and methods}

Production of synthetic mRNA and proteins

PCR with Vent polymerase (NEB) was used to generate deletions of the $X q u a^{357}$ coding sequence, starting with pSKXqua8c cDNA as a template (Zorn et al. 1997). Fragments were cloned into the expression vector pT TTS (a modified version of pSP64T; Krieg and Melton 1984) or pT7TS-HA, which provides an amino-terminal HA epitope tag. Templates pT TTS-Xqua ${ }^{357}$, pT TTS-Xqua ${ }^{365}$, pT TTS-HAXqua ${ }^{357}$, and the Xqua deletion constructions were linearized with BamHI and transcribed with T 7 RN A polymerase. pSPXM ax4 (Tonissen and Krieg 1994) was linearized with BamHI and transcribed with SP6 RN A polymerase. pXef1 (Krieg et al. 1989) was linearized with EcoRI and transcribed with T7 RN A polymerase. pFR, encoding the Xenopus fibroblast growth factor (FGF) receptor (a gift from Dr. E. Amaya, Wellcome/CRC Institute, Cambridge, UK), was linearized with Pstl and transcribed with SP6 RN A polymerase. pXK1 encoded the Xenopus hnRN P K (Siomi et al. 1993a). Synthetic capped mRN A was synthesized as described (Krieg and M elton 1984) or with the Mega-Script kit (Ambion) using cap analog (NEB). ${ }^{35} \mathrm{~S}$-labeled proteins were translated in vitro in reticulocyte lysates (BRL or Promega).

\section{RNA binding assays}

RN A binding of in vitro translated proteins was performed essentially as described by Swanson and Dreyfuss (1988). Binding reactions used $10^{5} \mathrm{cpm}$ of labeled protein and $30 \mu \mathrm{l}$ of RN Aagarose resin (10-60 $\mu \mathrm{g}$ of RN A) in $0.5 \mathrm{ml}$ of binding buffer ( 10 $\mathrm{mm}$ Tris- $\mathrm{HCl}$ at $\mathrm{pH} 7.5,100 \mathrm{~mm} \mathrm{NaCl}, 2.5 \mathrm{~mm} \mathrm{M} \mathrm{gCl}_{2}, 0.5 \%$ Triton X-100, and $0.1 \mathrm{mg} / \mathrm{ml}$ of BSA) for $10 \mathrm{~min}$ with rocking at $4^{\circ} \mathrm{C}$. The beads were washed five times with ice-cold binding buffer. Proteins bound to the RNA-agarose were released by boiling in SDS-protein sample buffer, resolved on SDS-PAGE, and visualized by fluorography. Homopolymer RNA-agarose was purchased from Sigma. Total Xenopus embryonic-agarose was generated as follows: RN A at $1 \mathrm{mg} / \mathrm{ml}$ in water was biotinylated with photoactivated biotin-acetate (Vector Labs) according to manufacturers instructions, and RNA-biotin was bound to streptavidin-agarose resin (BRL) at a final concentration of $0.1-2 \mu \mathrm{g}$ of RNA per $10 \mu \mathrm{l}$ of agarose resin.

\section{Immunoprecipitation}

Approximately one-fifth of the labeled proteins generated in a translation reaction were incubated with $5 \mu \mathrm{g} / \mathrm{ml}$ of monoclonal antibody $12 \mathrm{CA} 5$ (Boehringer $\mathrm{M}$ annheim) and $20 \mu \mathrm{l}$ of protein A-agarose (Sigma) in IP buffer (50 mM Tris- $\mathrm{HCl}$ at $\mathrm{pH} 7.5$, $150 \mathrm{~mm} \mathrm{NaCl}, 5 \mathrm{~mm} \mathrm{MgCl}_{2}, 1 \mathrm{~mm}$ EDTA, 0.25\% NP-40, $1 \mathrm{~mm}$ PMSF, and $1 \mathrm{~mm}$ DTT) for $2 \mathrm{hr}$ at $4^{\circ} \mathrm{C}$ with rocking. After precipitation, pellets were washed three times in ice-cold IP buffer and specifically bound proteins were eluted by incubation in 50 $\mu$ of $1 \mathrm{~mm}$ HA peptide (YPYDVPYA) (a gift from Dr. T. Kouzarides, Wellcome/CRC Institute, Cambridge, UK) at room temperature for $15 \mathrm{~min}$. Precipitated proteins were resolved on $10 \%$ SDS-PAGE and visualized by fluorography.

\section{GST fusion protein binding assays}

The Xqua ${ }^{357}$ coding sequence was cloned in-frame with GST in the vector pGEX-3X. GST-Xqua or GST al one (a gift from Dr. P. Lavender, Wellcome/CRC, Cambridge, UK) was expressed and purified on glutathione-Sepharose. Approximately one-fifth of the labeled proteins generated in a translation reaction were incubated with $2 \mu \mathrm{g}$ of GST-Xqua or GST alone coupled to glutathione-Sepharose in $500 \mu \mathrm{l}$ of binding buffer $(25 \mathrm{~mm}$ HEPES at pH 7.5, $12.5 \mathrm{~mm} \mathrm{M} \mathrm{gCl}_{2}, 150 \mathrm{~mm} \mathrm{KCl,} \mathrm{20 \%} \mathrm{glycerol,}$ $0.1 \% \mathrm{NP}-40,1 \mathrm{mM}$ DTT, and $1 \mathrm{mg} / \mathrm{ml}$ of BSA). Following 1 -hr incubation at room temperature, the Sepharose was pelleted and washed four times in NETN (20 mM Tris at pH 8, $100 \mathrm{~mm}$ $\mathrm{N} \mathrm{aCl}, 1 \mathrm{~mm}$ EDTA, and 0.5\% N P-40). The bound proteins were resolved on $12.5 \%$ SDS-PAGE and visualized by fluorography.

In situ hybridization, immunocytochemistry, and histology

Embryos and explants were fixed in MEMFA (Hemmati-Brivanlou and $\mathrm{H}$ arland 1989) for $2-3 \mathrm{hr}$ and then stored in methanol at $-20^{\circ} \mathrm{C}$. Whole-mount in situ hybridization was performed essentially as described by Harland (1991) with modifications detailed by Drysdale et al. (1994). Antisense DIG RNA probes, specific to the embryonic 5-kb Xqua mRN A, were transcribed from Notl linearized pSKXquallc cDNA template (Zorn et al. 1997). Other probe templates were prepared as described previously. pBSK Xnot-2 (Gont et al. 1993), pXbra (Smith et al. 1991), and pGsc (Cho et al. 1991). Whole-mount immunocytochemistry was performed using the following monoclonal antibodies. Anti-NCAM (Sigma, NCAM-OB11) for neural tissue, 12/101 (Kintner and Brockes 1984) for somite, and MZ15 (Smith and Watt 1985) for notochord. Embryos were rehydrated in $M A B$ (100 mm maleic acid at pH 7.5 and $150 \mathrm{~mm} \mathrm{~N} \mathrm{aCl}$ ), blocked for $2 \mathrm{hr}$ in BR-M AB [2\% blocking reagent (Boehringer M annheim) in $M A B]$, incubated with the appropriate antibody ( $1 / 200$ dilution in each case) overnight at $4^{\circ} \mathrm{C}$ in $\mathrm{BR}-\mathrm{MAB}$ followed by washing, $12 \times 30 \mathrm{~min}$ in MAB. These steps were repeated sequentially with rabbit anti-mouse Ig antibody (ICN , 1/200 dilution) followed by alkaline phosphatase-anti-alkaline phosphatase (APAAP; Boehringer $\mathrm{M}$ annheim, $5 \mathrm{U} / \mathrm{ml}$ ). Color reactions were performed either by NBT / BCIP (black) or BM Purple (Boehringer $M$ annheim). Stained embryos were fixed in Bouin's solution and photographed in benzyl alcohol/benzyl benzoate (1:2). Sections $(10 \mu \mathrm{m})$ were cut from tissue embedded in Histoplast/beeswax (98:2) followed by either staining with hematoxylin/eosin or double-immunostained with MZ15 and 12/101 as described in Carnac et al. (1996).

Xenopus oocytes and embryo manipulations

Oocytes were surgically removed from anesthetized female Xenopus, manually defolliculated, and cultured in $1 \times$ M BS (Gurdon 1977) at $18^{\circ} \mathrm{C}$. Oocytes were microinjected with $\sim 30 \mathrm{ng}$ of synthetic capped mRN A in a volume of $\sim 30 \mathrm{nl}$. After $16-24 \mathrm{hr}$ of incubation in the presence of $1 \mathrm{mCi} / \mathrm{ml}$ of $\left[{ }^{35} \mathrm{~S}\right]$ methionine, the nucleus was manually removed from the oocyte and both nuclear and cytoplasmic fractions were homogenized in IP buffer. Protein extracts were resolved on SDS-PAGE and visualized by fluorography. Embryos were cultured as described (Gurdon 1977) and staged according to N ieuwkoop and Faber (1967). Embryos, in 4\% Ficoll/MBS, were microinjected with synthetic mRNA (4.9 nl/blasotomere) and subsequently transferred to $1 / 10$ MBS. Dorsal-ventral polarity was predicted by differential pigmentation and verified by coinjection of GFP mRN A as a lineage marker (Zernicka-Goetz et al. 1996). Dorsal marginal zone tissue was dissected at stage 10-10.5, and two pieces of tissue were placed in opposition and cultured in $1 \times$ MBS.

\section{Acknowledgments}

We are grateful to Prof. J. B. Gurdon in whose lab the overexpression experiments were performed. We thank Gilles Carnac 
for advice and encouragement and E. Bellefroid, F. Stennard, and K. Ryan for critical reading of the manuscript. We thank Andy Mitchell for help with histology and P. Lavander and C. Le Chal ony for advice on the GST -fusion protein experiments. We especially thank T. Ebersole, Q. Chen, and K. Artzt for providing the original mouse quaking probe. A.M.Z. was supported by a $\mathrm{N}$ atural Sciences and Engineering Research Council of $\mathrm{Canada}$ postdoctoral fellowship and the Cancer Research Campaign. This work was supported by $\mathrm{N}$ ational Institutes of $\mathrm{H}$ eal th grant HD25179 to P.A.K.

The publication costs of this article were defrayed in part by payment of page charges. This article must therefore be hereby marked "advertisement" in accordance with 18 USC section 1734 solely to indicate this fact.

\section{References}

Bartoszewicz, Z.P., A.B. N oronha, N. Fujita, S. Sato, L. Bo, B.D. Trapp, and R.H. Quarles. 1995. Abnormal expression and glycosolation of the large and small isoforms of myelin-associated glycoprotein in dysmyel inating quaking mutants. J. Neurosci. Res. 41: 27-38.

Bode, V.C. 1984. Ethylnitrosourea mutagenesis and the isolation of mutant alleles for specific genes located in the t re gion of the mouse chromosome 17. Genetics 108: 457-470.

Braun, P.E., E. Horvath, and A.M. Edwards. 1990. Two isoforms of myelin-associated glycoprotein accumulate in quaking mice: Only the large polypeptide is phosphorylated. Dev. Neurosci. 12: 286-292.

Carnac, G., L. Kodjabachia, J.B. Gurdon, and P. Lemaire. 1996. The homeobox gene Siamois is a target of the Wnt dorsalisation pathway and triggers organiser activity in the absence of mesoderm. Development 122: 3055-3065.

Carnow, T.B., J.H. Carson, S.W. Brostoff, and E.L. Hogan. 1984. Myelin basic protein gene expression in quaking, jimpy and myelin synthesis-deficient mice. Dev. Biol. 106: 38-44.

Cho, K.W.Y., B. Blumberg, H. Steinbeisser, and E.M. DeRobertis. 1991. M olecular nature of Spemann's organizer: The role of the Xenopus homeobox gene goosecoid. Cell 67: 11111120.

Colman, A. 1984. Translation of eukaryotic messenger RN A in Xenopus oocytes. In Transcription and translation (ed. B. Hames and S. Higgins), pp 271-302. IRL, Oxford, UK.

Cruz-Alvarez, M. and A. Pellicer. 1987. Cloning of a full-length complementary DNA for an Artemia salina glycinerich protein. J. Biol. Chem. 262: 13377-13380.

De Boulle, K., A.J. Verkerk, E. Reyniers, L. Vits, J. Hendrickx, B. VanRoy, F. VanDen Bos, E. deGraaff, B.A. Oostra, and P.J. Willems. 1993. A point mutation in the FM R-1 gene associated with fragile $X$ mental retardation. Nature Genet. 3: 3135.

Draper, B.W., C.C. Mello, B. Bowerman, J. Hardin, and J.R. Priess. 1996. MEX-3 is a $\mathrm{KH}$ domain protein that regulates blastomere identity in early $C$. elegans embryos. Cell 87: 205-216.

Drysdale, T.A., K.F. Tonissen, K.D. Patterson, M.J. Crawford, and P.A. Krieg. 1994. Cardiac Troponin is a heart-specific marker in the Xenopus embryo: Expression during abnormal heart development. Dev. Biol. 165: 432-441.

Ebersole, T., Q. Chen, M.J. Justice, and K. Artzt. 1996. The quaking gene product necessary in embryogenesis and myelination combines features of RNA binding and signal transduction proteins. Nature Genet. 12: 260-265.

Fujita, N., S. Sato, T. Kurihara, T. Inuzuka, Y. Takahashi, and T. Miyatake. 1988. Developmentally regulated alternative splicing of the brain myelin-associated glycoprotein mRN A is lacking in the quaking mouse. FEBS Lett. 232: 323-327.

Fumagalli, S., N.F. Totty, J.J. Hsuan, and S.A. Courtneidge. 1994. A target for Src in mitosis. Nature 368: 871-874.

Gibson, T.J., J.D. Thompson, and J. Heringa. 1993. The KH domain occurs in a diverse set of RNA-binding proteins that include the anti terminator N usA and is probably involved in binding to nucleic acid. FEBS Lett. 324: 361-366.

Golbfarb, D. and N. Michaud. 1991. Pathways for the nuclear transport of proteins and RN As. Trends Cell Biol. 1: 20-24.

Gont, L.K., H. Steinbeisser, B. Blumberg, and E.M. De Robertis. 1993. Tail formation as a continuation of gastrulation: The multiple cell populations of the Xenopus tail bud derived from the late blastopore lip. Development 119: 991-1004.

Gont, L.K., A. Fainsod, S.-H. Kim, and E.M. De Robertis. 1996. Overexpression of the Homeobox gene Xnot-2 leads to notochord formation in Xenopus. Dev. Biol. 174: 174-178.

Gurdon, J.B. 1977. M ethods for nuclear transplantation in Amphibian. Methods Cell Biol. 16: 125-139.

Hamburger, V. 1988. Hanns Spemann and the Organiser. In The heritage of experimental embryology. Oxford University Press, Oxford, UK.

Hardy, R.J., C.L. Loushin, V.L. Friedrich, Q. Chen, T.A. Ebersole, R.A. Lazzarini, and K. Artzt. 1996. Neural cell typespecific expression of QK1 proteins is altered in quaking mutant mice. J. Neuro. Sci. 16: 7941-7949.

Harland, R.M. 1991. In situ hybridisation: An improved wholemount method for Xenopus embryos. Methods Cell Biol. 36: 685-695.

Hemmati-Brivanlou, A. and R.M. Harland. 1989. Expression of an Engrailed-related protein is induced in the anterior neural ectoderm of early Xenopus embryos. Devel opment 106: 611617.

Herrmann, B.G., S. Labeit, A. Poustka, T.R. King, and H. Lehrach. 1990. Cloning of the $T$ gene required in mesoderm formation in the mouse. Nature 343: 617-622.

Hogan, E.L. and S. Greenfield. 1984. Animal models of genetic disorders of myelin. In Myelin (ed. P. MorrelI), pp. 489-534. Plenum Press, N ew York, NY.

Jones, A.R. and T. Schedl. 1995. Mutations in gld-1, a female germ cell-specific tumor suppressor gene in C. el egans, affect a conserved domain also found in Src-associated protein Sam68. Genes \& Dev. 9: 1491-1504.

Justice, M.J. and V.C. Bode. 1988. Three ENU-induced alleles of the murine quaking locus are recessive embryonic lethal mutations. Genet. Res. Camb. 51: 95-102.

Kao, K. and M. Danilchik. 1991. Generation of body plan phenotypes in early embryogenesis. Methods Cell Biol. 36: 271284.

Kintner, C.R. and J.P. Brockes. 1984. Monoclonal antibodies identify blastema cells derived from dedifferentiating muscle in newt limb regeneration. Nature 308: 67-69.

Krieg, P.A. and D.A. M elton. 1984. Functional messenger RN As produced in vitro by SP6 in vitro transcription of cloned cDN As. Nucleic Acids Res. 12: 7057-7071.

Krieg, P.A., S.M . Varnum, W.M. Wormington, and D.A. Melton. 1989. The mRN A encoding el ongation factor $1-\alpha(E F-1 \alpha)$ is a major transcript at the midblastula transition in Xenopus. Dev. Biol. 133: 93-100.

Lock, P., S. Fumagalli, P. Polakis, F. McCormick, and S.A. Courtneidge. 1996. The human p62 cDN A encodes Sam68 and not the RasGap-associated p62 protein. Cell 84: 23-24.

Mahone, M., E.E. Saffman, and P.L. Lasko. 1995. Localized Bicaudal-C RNA encodes a protein containing a $\mathrm{KH}$ domain, the RNA binding motif of FMR1. EMBO J. 14: 2043-2055.

Musco, G., G. Stier, C. Joseph, M. Antonietta, C. Morelli, M. 
Nilges, T.J. Gibson, and A. Pastore. 1996. Three-dimensional structure and stability of the $\mathrm{KH}$ domain: Molecular insights into the Fragile X Syndrome. Cell 85: 237-245.

N ieuwkoop, P.D. and J. Faber. 1967. Normal table of Xenopus laevis (Daudin), 2nd ed. N orth-Holland, Amsterdam, N etherlands.

Piñol-Roma, S., Y.D. Choi, M.J. M atunis, and G. Dreyfuss. 1987. Immunopurification of heterogeneous nuclear ribonucleoprotein particles reveals an assortment of RNA-binding proteins. Genes \& Dev. 2: 215-227.

Powers, M.A. and D.J. Forbes. 1994. Cytosolic factors in nuclear transport: What's importin? Cell 79: 931-943.

Samorajski, T., R.L. Friede, and P.R. Reiner. 1970. Hypomyelination in the quaking mouse. A model for the analysis of disturbed myelin synthesis. J. Neuropathol. Exp. Neurol. 29: 507-523.

Shedlovsky, A., T.R. King, and W.F. Dove. 1988. Saturation germ line mutagenesis of the murine $t$ region including a lethal allele of the quaking locus. Proc. Natl. Acad. Sci. 85: 180-184.

Sidman, R.L., M.M. Dickie, and S.H. Appel. 1964. Mutant mice (quaking and jimpy) with deficient myelination in the central nervous system. Science 144: 309-311.

Siomi, H., M.J. M atunis, W. M atthew, and G. Dreyfuss. 1993a. The pre-mRNA binding $\mathrm{K}$ protein contains a novel evolutionary conserved motif. Nucleic Acids Res. 21: 1193-1198.

Siomi, H., M.C. Siomi, R.L. Nussabaum, and G. Dreyfuss. 1993b. The protein product of the fragile X gene, FM R1, has characteristics of an RN A-binding protein. Cell 74: 291-298.

Siomi, H., M. Choi, M.C. Siomi, R.L. N ussbaum, and G. Dreyfuss. 1994. Essential role for KH domains in RNA binding: Impaired RNA binding by a mutation in the $\mathrm{KH}$ domain of FM R1 that causes Fragile X Syndrome. Cell 77: 33-39.

Smith, J.C. and F.M. Watt. 1985. Biochemical specificity of Xenopus notochord differentiation. Development 29: 109115.

Smith, J.C., B.M.J. Price, J.B.A. Green, D. Weigel, and B.G. Herrman. 1991. Expression of a Xenopus homologue of Brachyury $(T)$ is an immediate-early response to mesoderm induction. Cell 67: 79-87.

Swanson, M.S. and G. Dreyfuss. 1988. Classification and purification of proteins of heterogeneous nuclear ribonucleoprotein particles by RN A-binding specificities. Mol. Cell. Biol. 8: 2237-2241.

Tal bot, W.S., B. Trevarrow, M.E. Halpern, A.E. M el by, G. Farr, J.H. Postlethwait, T. Jowett, C.B. Kimmel, and D. Kimelman. 1995. The organizer-specific homeobox gene floating head is essential for notochord development in Zebrafish. Nature 378: 150-157.

Taylor, S.J. and D. Shalloway. 1994. An RN A-binding protein associated with $\mathrm{Src}$ through its $\mathrm{SH} 2$ and $\mathrm{SH} 3$ domains in mitosis. Nature 368: 867-871.

Tonissen, K.D. and P.A. Krieg. 1994. Analysis of a variant Max sequence expressed in Xenopus laevis. Oncogene 9: 33-38.

Urlaub, H., V. Kruft, O. Bischof, E.-C. Muller, and B. WittmannLiebold. 1995. Protein-rRNA binding features and their structural and functional implications in ribosomes as determined by cross-linking studies. EMBO J. 14: 4578-4588.

Vize, P.D., D.A. M elton, A. Hemmati-Brivanlou, and R.M. Harland. 1991. Assays for gene function in developing Xenopus embryos. Methods Cell Biol. 36: 367-387.

Wang, L.L., S. Richard, and A.S. Shaw. 1995. p62 Association with RNA is regulated by tyrosine phosphorylation. J. Biol. Chem. 270: 2010-2013.

Wong, G., O. Muller, R. Clark, L. Conroy, M.F. Moran, P. Polakis, and F. McCormick. 1992. Molecular cloning and nucleic acid binding properties of the GAP-associated tyrosine phosphoprotein p62. Cell 69: 551-558.

Zernicka-Goetz, M., J. Pines, K. Ryan, K.R. Siemering, J. Haseloff, M.J. Evans, and J.B. Gurdon. 1996. An indelible marker for Xenopus using a mutated green fluorescent protein. Development 122: 3719-3724.

Zhang, Y., J.P. O'Conner, M.C. Siomi, S. Srinivasan, A. Dutra, R.L. N ussbaum, and G. Dreyfuss. 1995. The Fragile X Mental Retardation Syndrome protein interacts with novel homologs FXR1 and FXR2. EMBO J. 14: 5358-5366.

Zorn, A.M., M. Grow, K.D. Patterson, T.A. Ebersole, Q. Chen, K. Artzt, and P.A. Krieg. 1997. Remarkable sequence conservation of transcripts encoding amphibian and mammalian homologues of quaking, a KH-domain RN A-binding protein. Gene 188: 199-206. 


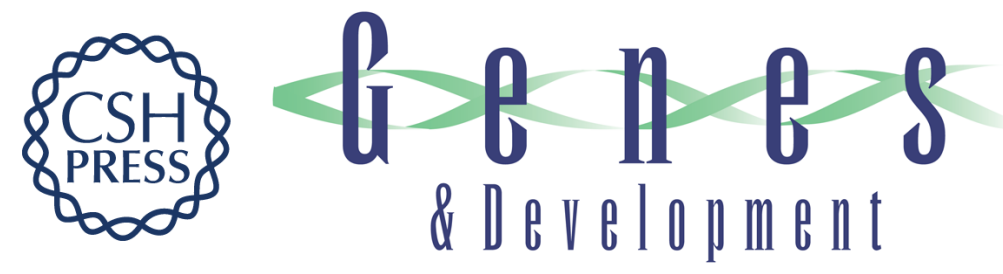

\section{The KH domain protein encoded by quaking functions as a dimer and is essential for notochord development in Xenopus embryos}

Aaron M. Zorn and Paul A. Krieg

Genes Dev. 1997, 11:

Access the most recent version at doi:10.1101/gad.11.17.2176

\section{License}

Email Alerting

Service

Receive free email alerts when new articles cite this article - sign up in the box at the top right corner of the article or click here.

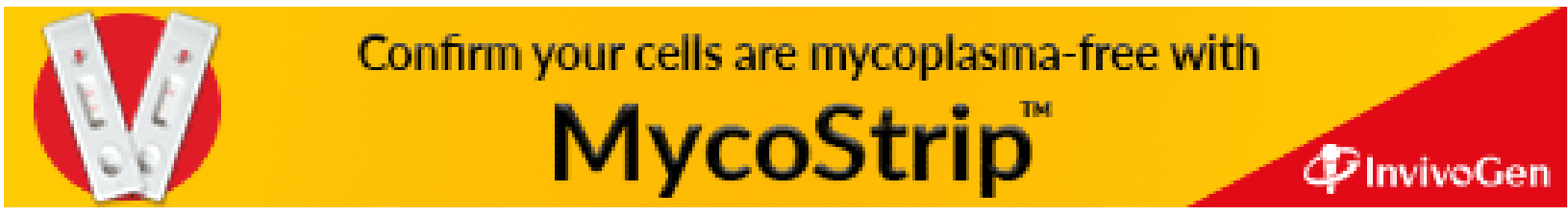

